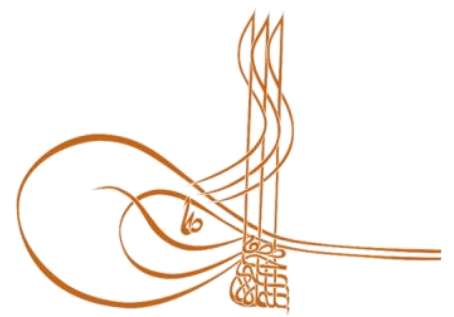

www.turkishstudies.net/economy
TurkishStudies-Economics, Finance, Politics

eISSN: $2667-5625$

ResearchArticle / Araștırma Makalesi

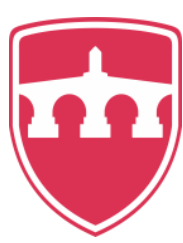

INTERNATIONAL BALKAN

UNIVERSITY

Sponsoredby IBU

\title{
Lojistik Faaliyetlerde Bilişim Teknolojileri Kullanılmasının Üretim İşletmesi Organizasyonuna Etkisi
}

\author{
TheEffect of Using Information Technologies on LogisticsActivitiesin theProduction Business \\ Organization
}

\author{
Ahmet Alper Sayın* - Kübra Irkl1 ${ }^{* *}$
}

\begin{abstract}
As the innovations brought by technological developments create a competitive environment formany companies, enterprises have made it necessary to specialize in this field. In his book Greengard (2017), he introduced the concept of technology adaptation curve, which is now widely accepted. With this concept, it has been suggested that every new product or solution follows a highly predictable course, roughly forming a bell curve. In his work, those who adapted to the technology were called "innovative", and those who were pioneers in these condphase were named "earlyadapted", and those who appealed to them ases were called "traditionalists". Although this model is stil valid, the life cycle has accelerated at a radical pace in the past few decades. For this reason, companies should adapt to technology and make the irinternal transformations as soon as possible. The high impact of logistics activities in enterprises in different sectors shows that logistics is an important change and cost key for companies. Therefore, logistics activities are expected to increase this effect by supporting them within formation technologies. Within the scope of digital transformation concept, it is possible to develop systems and processes effectively and efficiently in the basic elements of logistics with a technological change in business processes. In this review, the strategies that provide effective solutions to all company activities, from automation systems included in digital transformation to stock systems in warehouses, are mentioned. In ourstudy; in the development of a multinational production company, the results based on the interview that convey the effects of theuse of information technologies in logistics activities on the company were shared. By using information technologies in logistics activities in the production enterprise, its relationship with the performance enhancing effect has been revealed in the entire organization chain in the enterprise.
\end{abstract}

*Dr. Öğr. Üyesi, Karamanoğlu Mehmetbey Üniversitesi, Uygulamalı Bilimler Yüksekokulu, Uluslararası Ticaret ve Lojistik Yönetimi Bölümü

Asst. Prof. Dr., Karamanoglu Mehmetbey University, School Of Applied Sciences, International Trade And Logistics Management

ORCID0000-0002-2086-6763

ahmetalpersayin@kmu.edu.tr

*** Karamanoğlu Mehmetbey Üniversitesi, Uluslararası Ticaret ve Lojistik Yönetimi A.B.D.

Karamanoglu Mehmetbey University, Trade And Logistics Management MBA

ORCID0000-0002-3160-6094

irklikubra@gmail.com

Cite as/ Atıf:Sayın, A. A., Irklı K. (2020). Lojistik faaliyetlerde bilişim teknolojileri kullanılmasının üretim işletmesi organizasyonuna etkisi, TurkishStudies-Economy, 15(1), 519-540. https://dx.doi.org/10.29228/TurkishStudies.41515

Received/Geliş:29 January/Ocak 2020

Checkedbyplagiarism software

Accepted/Kabul:25March/Mart 2020

Published/Yayın: 30March/Mart 2020

Copyright (C) INTAC LTD, Turkey

CC BY-NC 4.0 


\section{Structured Abstract: Introduction and Purpose of the Study}

Within the scope of digital transformation concept, it is possible to develop systems and processes effectively and efficiently in the basic elements of logistics with a technological change in business processes. In this review, the strategies that provide effective solutions to all company activities, from automation systems included in digital transformation to stock systems in warehouses, are mentioned. Practical solutions to be offered by information technologies are mentioned in the application areas used in the company. The aim of the study is to observe the performance impact of technological systems on all the organizational branches of the company, especially through logistics activities. Depending on the research model, the hypothesis of the research;

H1: There is a relationship between the use of information technologies in logistics management and business activities.

$\mathrm{H} 2$ : There is a relationship between the use of information technologies and customer satisfaction in logistics management in the enterprise.

\section{Conceptual Framework of the Study Subject}

The pre-production stages of the company, the management, supervision and decision-making mechanisms carried out during the production and post-production phases are given in detail and the effect of the information technologies used in the operational processes is clearly determined. How the operational flows of the company took place and all information technologies involved during the process were examined and supported with visuals. In addition, the study sites at the location of the company subject to the research were observed, the technologies used in the management systems of these sites, why they preferred these technologies, the advantages and disadvantages of these systems were questioned. The features, costs and performance criteria of the equipment used in the company site are provided with detailed information and the opportunity to compare with different technologies is provided. The positive and negative effects of the management systems used in the company for the company, personnel and the customer were investigated. Optimization solutions offered for many departments have been mentioned and the causes, objectives and results of supported R\&D studies have been investigated.

Technological investment plans are mentioned in line with the company's future targets. In this regard, answers were sought for the technologies that have recently been applied and whether these technologies meet the expectations. The reason why the company needs information and management technologies, the benefits it provides from these technologies, the risks caused by this technology and the precautions it takes against these risks were investigated. Social and environmental responsibilities of the company while using these technologies were also examined. Company staff's suggestions, opinions and determinations about the current system were learned. Thus, the functioning of the system is compared with internal and external observations. Considering that the company is a widely used brand, it was possible to compare personal and professional experiences. Since this review was conducted in a company with a high level of development, it was found that the rate of use of new technologies was high.

\section{Method}

In the direction of the research hypothesis, a literature review was made, and the method and model of the research were determined. The sample of the research was determined as the factory of the production company in Konya. In the data collection phase, it started with the research of general information about the company and was concluded with a semi-formal interview technique. Detailed information about the location of the researched company, its operations, equipment and management systems are included. This information is supported by visuals and numerical data.

\section{Findings}

As a result of the review, it is seen that the support of logistics systems with technology strengthens many critical operating factors such as management and control mechanisms. It is clearly seen that information technologies increase the efficiency of the systems and provide speed and practicality for each field directly and indirectly connected. Thanks to the integrated systems, it has been observed that it creates an effective structure in returns with the use of information. This development also indicates that products and services will improve and become cheaper, but security will increase. It is seen that the instant sharing of information in a system in which each department is interconnected in the production enterprise provides 
advantages in many issues. At this point, technological developments are projected in direct proportion to the needs of all small, medium and large companies.

In line with the optimization solutions offered by the company, which is the subject of the research, the impact of information technologies has been clearly seen. In the light of the data obtained, the strengths, weaknesses and opportunities and threats posed by the information technologies in a production company were determined with the swot analysis made for the company. In terms of customer satisfaction of the company; corporate relations, public relations department, communication functions were examined and the relationship between information technologies and these business functions was questioned. In terms of the company's operating performance; marketing, finance, $R \& D$ and accounting departments were examined and the relationship of information technologies with these departments was questioned. In terms of the logistics activity performance of the company; The relationship between functions such as production and operational management, warehouse-inventory management, handling activities, distribution management, order management and information management with information technologies were examined.

\section{Conclusion}

It is observed that the impact of the use of information technologies in the production enterprise and logistics activities on the firm performance is quite high. The suggestions shared by the company official with the semi-formal interview technique are included in the text and it is provided to shed light on future research. As a result, predicted at the beginning of the study; The relationship hypothesis between the use of information technologies in business logistics management and business activities and customer satisfaction was supported by the information obtained as a result of the research.

Keywords: Logistics activities, Information systems, Activity performance

Öz: Teknolojik gelişmelerin getirdiği yenilikler pek çok şirket için rekabet ortamı oluşturduğundan dolayı, işletmelerin bu alanda uzmanlaşmayı mecburi kılmıştır. Greengard (2017) kitabında, artık yaygın olarak kabul edilen teknoloji adaptasyon eğrisi kavramını ortaya atmıştır. Bu kavramla, her yeni ürünün ya da çözümün kabaca bir çan eğrisi oluşturan, oldukça tahmin edilebilir bir gidişat izlediğini ileri sürülmüştür. Çalışmasında, teknolojiye ilk adapte olanlara "yenilikçi" adı, ikinci evreye öncü olanların ismini ise "erken adapte" olanlar, geniş kitlelere hitap edenlere ise "gelenekçiler" adı verilmiştir. Bu model hâlâ geçerliliğini korusada, son birkaç on yılda yaşam döngüsü radikal bir hızla ivme kazanmıştır. Bu nedenle, şirketler teknolojiye adapte olmalı ve şirketi içi dönüşümlerini mümkün olan en kısa sürede gerçekleştirmelidirler. Lojistik faaliyetlerin farklı sektörlerdeki işletmelerde oluşturduğu yüksek etki, lojistiğin şirketler için önemli bir değişim ve maliyet anahtarı olduğunu göstermektedir. Dijital dönüşüm kavramı kapsamında, iş süreçlerinde gidilecek teknolojik bir değişim ile lojistiğin temel unsurlarında etkin ve verimli olarak sistemleri ve süreçleri geliştirmek mümkün olmaktadır. Bu incelemede dijital dönüşüme dahil olan otomasyon sistemlerinden depolardaki stok sistemlerine kadar tüm şirket faaliyetlerine etkili çözümler sunan stratejilerinden bahsedilmiştir. Dolayısıyla lojistik faaliyetlerin bilişim teknolojileri ile desteklenerek bu etkiyi oldukça büyütmesi beklenmektedir. Çalışmamızda; çok uluslu bir üretim işletmesinin gelişiminde, lojistik faaliyetlerde bilişim teknolojilerinin kullanımının, firma üzerindeki etkilerini aktaran mülakat görüşmesine dayalı sonuçlar paylaşılmıştır. Üretim işletmesinde lojistik faaliyetlerde bilişim teknolojilerini kullanılmasıyla işletmedeki tüm organizasyon zincirinde, performans artırıcı etkisi ile ilişkisi ortaya konulmuştur.

Anahtar Kelimeler: Lojistik faaliyetler, Bilişim sistemleri, Faaliyet performansı

\section{Giriş}

Bu bölümde günümüzde etkisi hızla artan ve her sektör için bir değişim sürecini mecbur kılan bilişim teknolojilerinin işletmelerdeki lojistik faaliyetler üzerindeki etkisi betimlenecektir. Bilişim teknolojileri pek çok işletme fonksiyonunu aynı anda yönetmeyi ve bu fonksiyonların koordinasyon halinde çalışmasını sağlamaktadır. Büyük şirketlerdeki birçok değişkenin kontrol altında tutulabilmesi, yönetilebilmesi, problemler karşısında efektif kararlar alınabilmesi ve analizler doğrultusunda yeni stratejilerin geliştirilmesi bilişim teknolojileri etkisi ile gerçekleştirilmektedir. Bilişim teknolojileri tüm sistemleri pratik ve profesyonel hale getirmektedir. 
Büyük şirketlerin teknolojik yatırımlara eğilimi gözlemlendiğinde, bu gelişime açık ve istekli oluşları sağlayacağı faydayı göstermektedir. Pek çok şirket piyasada ayakta kalabilmek için bu değişime mecburdur. Başarılı firmaların geçmişleri incelendiğinde yüksek meblağlı teknolojik yatırımlar konusunda uzun vadeli hesaplamalar yaparak bu kararları aldıkları görülmektedir.

Belirli bir seviyeye ulaşmış firmalar ürettikleri ürün veya hizmet standartlarında birbirlerine çok yaklaşık kalite standardını yakalayabilmektedir. Rekabet ortamında var olabilmek için tüketiciyi kendi markalarına çekecek başka yollar bulmaları gerekmekte ve bununla birlikte maliyeti başka kalemlerde düşürmeleri gerekmektedir. Rekabet ortamını bu noktada kızıştıran unsur zaman kavramı olmaktadır. Nitekim hız, şirketleri bir adım öne çıkaracak en önemli unsurlar arasında ilk sıralardadır. Hız kavramı şirketin her operasyonunda etkili olmaktadır. Bu bir üretim firmasında temel olarak yönetim aşaması, üretim aşaması, tedarik aşaması, dağıtım aşaması ve geri dönüş aşaması olarak belirtilmektedir. Bir hizmet firmasında da benzer başlıklar oluşturulmaktadır. Ürün yerine hizmet üretimi, hizmetin tüketiciye sağlandığ belirtilmektedir. Bu operasyonların her biri hız konusunda kritik sonuçlar doğurmaktadır.

Günümüzde bilişim teknolojileri hız ihtiyacını karşılama konusunda en yüksek paya sahiptir. İşletmelerin lojistik faaliyetlerine bilişim teknolojilerini dahil etmeleri bu hususlarda başarılı bir sonuç elde etmeleri adına önemli bir seçim olmaktadır. Sonuç olarak bu çalışmada; çok uluslu bir üretim işletmesinin gelişiminde lojistik faaliyetlerde bilişim teknolojilerinin kullanımının firma üzerindeki etkilerini aktaran mülakat görüşmesine dayalı sonuçlar paylaşılacaktır ve bir üretim işletmesinin lojistik faaliyetlerde bilişim teknolojilerini kullanarak, işletmedeki tüm organizasyon zincirinde performans artırıcı etkisi ile ilişkisi ortaya konulacaktır.

\section{Literatür Araştırması}

Sondergaard'ın 2011'de kullandığ1 “'Bilgi, 21. yüzyılın petrolü olacaktır!' ifadesi bilginin hayati önemine dikkat çekmektedir (Chaudhari ve Binita, 2017: 597). Bilgi, sürekli ve hızla gelişmekte olan dünya sisteminde pek çok değişimin başlangıcı olmaktadır. Teknolojinin katlanarak yükselişi, bilgi toplumunu meydana getirerek küreselleşme kavramının kabul görmesini hızlandırmaktadır (Temel ve Yapraklı, 2015: 2).

Küreselleşme, yalnızca bilgi teknolojilerinin devamlı gelişmesi ve sürekli artış gösteren pazar alanları ile değişim göstermemektedir ayrıca yeni gelişen kavramları da içerisinde barındıran, pek çok farklı özelliği bulunan, olay ve hareketler dizisidir (Power, 2000: 1). Küreselleşmenin bu tanımında, bilişim teknolojilerinin değişim üzerindeki etkisinden bahsedilmektedir. Bilişim Teknolojileri, işılenmemiş ham bilginin, anlamlandırılarak kullanıcıları için faydalı hale getirilmesidir. İşlenmemiş olan bilgileri bir araya getirip saklayarak ve ağlar vasıtasıyla ulaşım kanalları oluşturarak kullanıcılarıyla paylaşmaktadır (Çağlar, 2014: 43).

Lojistik faaliyetlerde bilişim teknolojileri bilginin doğrudan ve hızlı bir şekilde kullanılmasını sağlamaktadır. Organizasyonlarda kalıp çalışmanın dışına çıkarak karar almada esneklik sağlamakta dolayısıyla herkese açık bir işletme ortamı oluşturmaktadır (Drucker, 1988: 4). Bilişim teknolojileri, efektif haberleşme ve denetim mekanizmaları geliştirmektedir (Aydıner ve Tatoğlu, 2019: 60).

\section{Araştırma}

$\mathrm{Bu}$ araştırmada, dünya çapında ilk 500 gelir sıralamasına göre ilk 200 de olan hızlı tüketim ürünleri üretimi yapan $\mathrm{ABC}$ şirketinin Konya tesisi (çalışma boyunca $\mathrm{ABC}$ şirketi olarak anılacaktır) örnek olay olarak ele alınmaktadır. Bu doğrultuda öncelikle firma hakkında herkese açık internet kaynaklarından elde edilen genel bilgilere yer verilmektedir. Daha sonra mülakat sonucunda ortaya çıkan bilgiler sunulacaktır. 


\section{Araştırmanın Yöntemi ve Modeli}

$\mathrm{Bu}$ çalışmanın amacı, global bir üretim işletmesi lojistik faaliyetler gerçekleştirirken bilişim sistemleri kullanmasının, firmadaki bütün organizasyon yapılarına etkisi belirlenmektedir. Etkinin her bakımdan değerlendirilmesinin yapılması ve izah edilmesi için örnek olay çalışması gerçekleştirilmiştir (Yin, 1994: 12). Örnekleme konu olan şirketin yetkilisi ile e-posta ve telefon üzerinden önceden belirlenen tarihte görüşmeler planlamıştır. Bu araştırmada yarı biçimsel mülakat yöntemi kullanılmıştır. Yaklaşık 2 saat süren görüşme esnasında yazılı notlar alınmış ve araştırma konusuyla ilgili depo ve üretim tesisleri gezilerek görüntü alınmıştır. Araştırma deseni aşağıdaki ana sorunun ve alt soruların cevaplanmasına imkân sağlamaktadır:

1. Hızlı tüketim ürünleri üretim işletmelerinin lojistik faaliyetlerinde bilişim teknolojileri kullanmalarının, şirketin genel performansı üzerindeki etkisi nedir?

Alt sorular:

a) Firmanızda depolama, taşımacılık, paketleme, elleçleme vb. gibi yapılan lojistik faaliyetler nelerdir?

b) Lojistik faaliyetlerin geliştirilmesi için kullanılan karar destek sistemleri, yönetici ve yönetim bilişim sistemleri nelerdir?

c) Firmanızda lojistik faaliyetler için kullanılan bilgi sistemlerinde karar alma, operasyonların kontrol edilmesi, sorunların analiz edilmesi ve yeni ürün veya hizmetler üretilmesi noktasinda uygulamalarınız nelerdir?

d) Lojistik faaliyetlerde geri dönüş yönetimini nasıl yapıyorsunuz, hangi teknolojileri kullaniyorsunuz?

e) Firmanızda lojistik faaliyetler için kullanılan mobil ve diğer dijital uygulamaları nelerdir?

f) Bu uygulamalar hangi işletme fonksiyonlarını desteklemektedir? Faaliyet verimliliği ve karar vermeyi nasıl etkilemektedir? Maliyetleri nedir?

g) Firmanızda satış eğilim analizi (lojistik faaliyetler açısından) için bir uygulama kullanıyor musunuz, kullanıyorsanız hangi uygulamayı kullanıyorsunuz? Size sağladığı yararlar nelerdir? (Hangi ürünler yeniden stoklanacak, satılan miktar ve satışlar ile ilgili diğer bilgilerin yer aldığ 1 veritabanı için kullandığınız yazılımlar ve bu verilerin kaydedildiği teknolojik cihazlar gibi detaylar)

h) Firmanızın Lojistik iş süreçleri nelerdir? Bilgi sistemleriyle nasıl ilişkilidir? halde midir?

i) Şirketinizin sistemi müşterileriniz ve büyük tedarikçilerinizim sistemi ile bütünleşmiş

j) Firmada lojistik faaliyetlerde kullanılan teknolojiler nelerdir, bu stratejiler işletme stratejisi ile nasıl ilişkilendirilebilir, yaklaşık maliyetleri nelerdir? Satış gelirlerine etkisi nedir?

k) Stok-envanter yönetimini nasıl gerçekleştiriyorsunuz? Hangi iş süreçlerini takip ediyorsunuz ve kullandığınız teknolojiler nelerdir? Bu teknolojilerin firmanız için maliyeti nedir?

1) Tedarik zinciri optimizasyonu için hangi çözümleri kullanıyorsunuz? Bu konuda kullandığınız yazılımlar ve maliyetleri nelerdir?

m) Firmada taşımacılık faaliyetinde kullanılan bilgi teknolojilerinin işletmeye sağladığ katk1lar nelerdir?

n) Firmada taşımacılık faaliyetinde kullanılan bilgi teknolojilerinin kullanımında işletmenin karşılaştığı sorunlar nelerdir? 
o) Firmanın taşımacılık faaliyetinde kullanılan bilgi teknolojilerinin, rakip firmalardaki durumu nedir? neden?

p) Firmadaki lojistik sorumlularının mevcut sisteme karşı önerdiği sistemler nelerdir ve

q) Firmada taşımacılık faaliyetinde kullanılan bilgi teknolojilerinin SWOT analizini yapınız.

r) Taşımacılık faaliyetinde kullanılan coğrafi bilgi sistemleri nelerdir? Maliyeti ve Ekonomik Açıdan Değerlendirilmesi, şirketin verimliliğine etkisi nedir? Riskleri nelerdir? Vb.

s) Rota optimizasyonu için kullandığınız teknolojiler nelerdir?

t) Dijital dönüşüm kavramının firmanızdaki karşılığı nedir? Bu kapsamda çalışmalarınız var m1, varsa neler? var $\mathrm{m} 1$ ?

u) Büyük veri (Big data) ve Nesnelerin interneti (Internet of things) ile ilgili çalışmalarınız

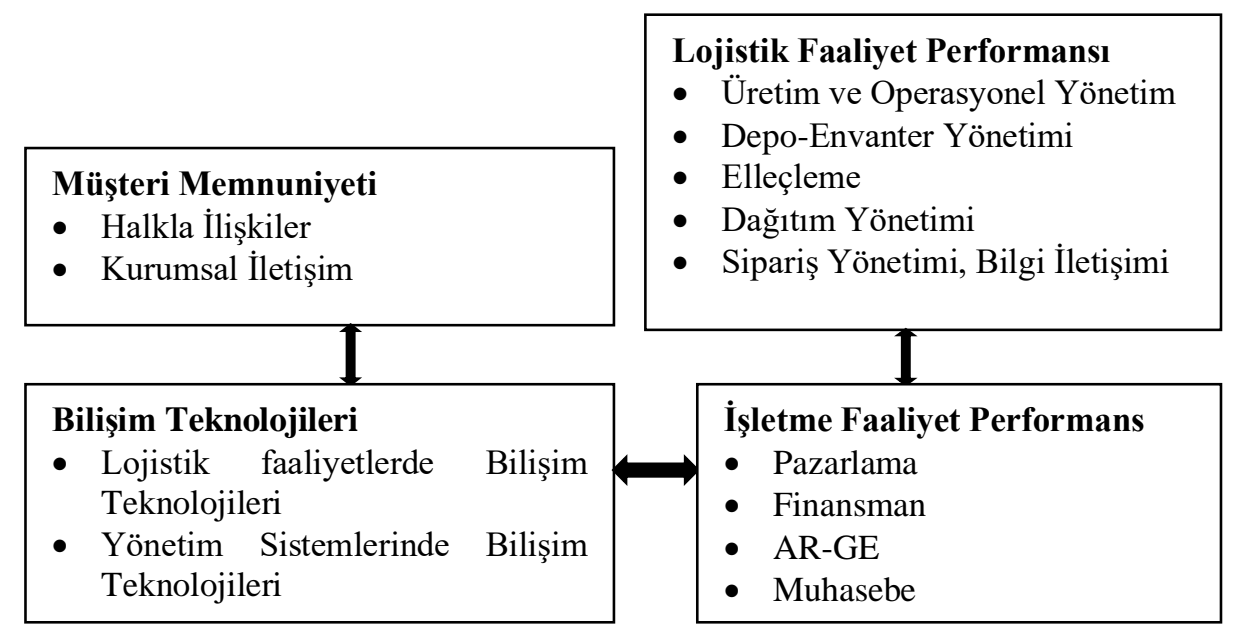

Şekil 1. Araştırma Modeli

Araştırma modelinde; firmadaki bilişim teknolojilerinin, lojistik faaliyet performansı, işletme faaliyet performansı ve müşteri memnuniyeti ile etkileşimi ve etkilerinin incelenmesi amaçlanmaktadır. Bilişim Teknolojileri; lojistik faaliyetlerde bilişim teknolojileri ve yönetim sistemlerinde bilişim teknolojileri gibi değişkenlere sahiptir. Lojistik faaliyet performansı; üretim ve operasyonel yönetim, depo-envanter yönetimi, elleçleme, dağıtım yönetimi ve sipariş yönetimi, bilgi iletişimi gibi değişkenlere sahiptir. İşletme faaliyet performansı; pazarlama, finansman, ARGE ve muhasebe gibi değişkenlere sahiptir. Müşteri memnuniyeti; halkla ilişkiler ve kurumsal iletişim gibi değişkenlere sahiptir. 
Araştırma modeline bağlı olarak araştırmanın hipotezi;

$\mathrm{H}_{1}$ : İşletmede lojistik yönetiminde bilişim teknolojilerinin kullanımı ile işletme faaliyetleri arasında bir ilişki vardır.

$\mathrm{H}_{2}$ : İșletmede lojistik yönetiminde bilișim teknolojilerinin kullanımı ile müşteri memnuniyeti arasında bir ilişki vardır.

\section{Örneklem}

Tablo 1. Örneklemin özellikleri

\begin{tabular}{lc}
\hline Örneklemin Özellikleri & Sayısı/ Fiyatı \\
\hline $\begin{array}{l}\text { Otomatik Depolama ve Alma Sistemi (AS/RS) } \\
\text { Deposu Toplam İnşaat Alanı }\end{array}$ & $48.000 \mathrm{~m}^{2}$ \\
\hline $\begin{array}{l}\text { Otomatik Depolama ve Alma Sistemi(AS/RS) } \\
\text { Depo Palet Kapasitesi }\end{array}$ & 76.300 \\
\hline Fabrika Toplam İnşaat Alanı & $50.057 \mathrm{~m}^{2}$ \\
\hline Yatırım Değeri & $350 \mathrm{Milyon} €$ \\
\hline Toplam Üretim Kapasitesi & 750 Bin Ton \\
\hline Firma Tesis Sayısı & 9 adet \\
\hline Firma Otomasyon Kullanım Yüzdesi & $\% 97$ \\
\hline
\end{tabular}

Araştırma evreni hızlı tüketim ürünleri üreten işletmeler olarak belirlenmiştir ve araştırmanın yapıldığı tarihte, kuruluş onayı alınarak ölçüt örnekleme yöntemi ile bilişim teknolojileri kullanımı yüksek olan ABC şirketinin Konya'daki fabrikası örneklem olarak belirlenmiştir. Burada toplamda 9 tesis mevcuttur. 4 adet üretim tesisi, 2 adet șişe üretim tesisi, 1 adet dolum tesisi, 1 adet büyük depolama-dağıtım tesisi ve 1 adet de hammadde lojistik tesisi bulunmaktadir.

\section{Nitel Örneklem Verilerin Toplanması}

Firma hakkında genel bilgiler internet üzerinden edinilmiş ve görüşme esnasında alınan bilgilerle desteklenmiştir. Yarı biçimlendirmiş mülakat yönetimi ile gerçekleştirilen görüşme için firmanın yetkili birimleri ile irtibat kurularak daha önceden belirlenen görüşme soruları sorulmuştur. Görüşmede alınan notlar metin haline dönüştürülmüş ve çekilen görüntüler araştırma yer verilmiştir. Tedarik zinciri köyü adı verilen yerde depolama alanlarının, üretim alanlarının, yönetim binalarının ve tedarikçi firmaların olduğu tespit edilmiştir. Lojistik faaliyetleri içeren bilişim sistemleri incelenmiştir. Firmanın piyasadaki büyük payı ve kritik bilgi içerikleri ve birlikte çalıştığı diğer firmalarında özel bilgilerini içeren verilerin paylaşılamaması ve ayrıca piyasadaki gizlilik ilkeleri araştırmanın kısıdını oluşturmaktadır.

\section{Bulgular}

\section{Firma Hakkında Genel Bilgiler}

'ABC' firmas1 1920-1929 y1lları arasında İngiltere'de sabun ve margarin üretimi yapan farklı sektörlerden iki büyük firmanın birleşmesiyle oluşturulmuştur. Alanlarında uzman pek çok firmayı bünyesine katarak büyümeye devam etmiştir.

1940'lı yıllarda gıda pazarında büyümesi halen devam etmiştir. Bu dönemlerde balık, dondurma ve konserve yiyecekler $\mathrm{ABC}$ ' nin toplam cirosunun sadece $\% 9$ 'unu kapsamıştır.

1950'li yıllara gelindiğinde ABC, Gıda ve Sağlık Araştırma enstitüsü kurmuş ve bununla birlikte bilimsel gelişmelerin artmasıyla teknolojiye odaklanmaya başlamıştır. Yine bu seneler içerisinde biyoloji araştırmaları için hususi bir departman kurulmuştur. 1950'li yılların ortaların ABC firması Türkiye' pazarına giriş yapmıştır. 1950'li yılların sonlarına gelindiğinde kişisel bakım alanında markalaşmış bir ürününü dünya çapında 18 ülkede satmıştır. Yine bu yıllarda ilk reklam 
filmini yayınlamıştır. Yaptığı sosyal ve ilgi çekici organizasyonlarla markasını pek çok ülkeye tanitmaya devam etmiştir.

1960'11 yıllarda dünya ekonomisindeki büyümesini devam ettirmiştir. Bu sırada halen yenilikler yaparak ve satın alımlar gerçekleştirerek ürün çeşitliliğini artırmıştır. Yine 1960'lı yılların ortalarında kurum içi uzman hizmet sağlayıcılarını kâr getiren işletmeler haline çevirmiştir.

1970'li yılların sonuna doğru Avrupa'da 200 ofis sayısına ulaşmış ve yaklaşık 177.000 kişiyi istihdam etmiştir. Sabit varlığ yaklaşık 1 milyar $£$ harcama yapmıştır. Avrupa merkezli bu şirketin ABD'deki en büyük yatırım 1970'li yılların sonunda olmuştur.

1980’lere gelindiğinde dünyanın en büyük 26. şirketi konumuna yükselmiştir. Bu yıllardan itibaren 10 yıllık süreçte strateji değiştirerek satın aldığı pek çok firmayı bünyesinden tasfiye etmiş ve temel ürün alanlarında verimlileştirmeye yönelerek fark edilir düzeyde büyüme kaydetmiştir.

1990'l1 yıllarda ürün çeşitliliğini 50'den 13'e düşürmüş ve yüksek potansiyel içeren ürün sınıfları üzerine odaklanmıştır. Bu şekilde; yiyecek, ev bakımı, kişisel bakım ve özel kimyasallar olarak 4 temel alan oluşturmuştur. Bu yıllarda tüketicilerin gıdalar konusundaki endişeleri artmış, çevresel hassasiyet oluşmuş ve bu doğrultuda baskılar büyümüştür. Buna yönelik sürdürülebilir çevre politikaları geliştirilmiş ve doğal kaynakların korunması ile ilgili sorumluluk projeleri başlatmıştır.

2000'li yıllarda bünyesindeki marka sayısı 900 adete ulaşmıştır. 2010'lu yılların başlarında toplam cirosu 50 milyar $€$ 'yu aşmıştır. Her yıl 14 ayrı markanın 1 milyar $€$ ' yu geçkin satış1 bulunmaktadır. 2019 yılında yaklaşık 60, 200.00 \$ (\$M) geliri, 11,150.00 \$ (\$M) kâr1, 68,000.00 \$ $(\$ M)$ varlığ ve 155,000 çalışanı olduğu açıklanmıştır. Günümüzde Türkiye'de toplam 8 fabrika ve yaklaşık 5.000 çalışan ile hizmet vermektedir.

Tablo 2: Firmanın yıllara bölünmüş kâr tablosu

\begin{tabular}{lccccc}
\hline Kategori/YIl & $\mathbf{2 0 1 5}$ & $\mathbf{2 0 1 6}$ & $\mathbf{2 0 1 7}$ & $\mathbf{2 0 1 8}$ & $\mathbf{2 0 1 9}$ \\
\hline Kâr (\$M) & $6,859.5$ & 5,445 & $5,732.7$ & $6,823.00$ & $11,080.60$ \\
\hline Gelir (\$M) & $64,251.8$ & 59,093 & 58,292 & 60,548 & $60,167.30$ \\
\hline Varlık (\$M) & $58,108.9$ & 56,806 & 59,512 & $72,388.30$ & $67,958.20$ \\
\hline $\begin{array}{l}\text { Çalışan Sayısı } \\
\text { (Bin) }\end{array}$ & 173.000 & 171.000 & 168,832 & 160,566 & 154,848 \\
\hline
\end{tabular}

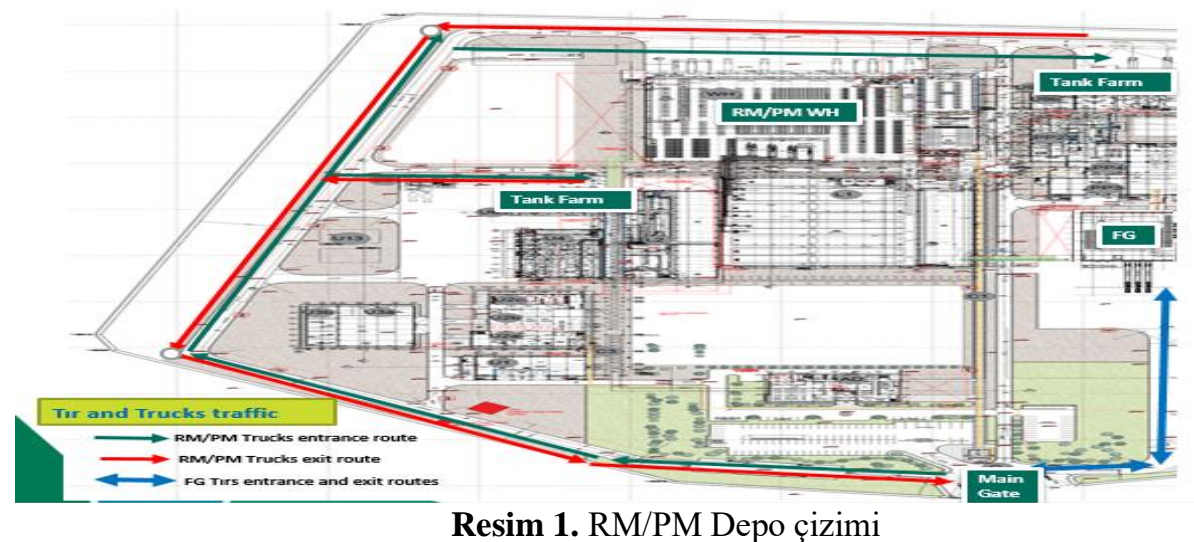

Fabrikanın konumu 'Tedarik Zinciri Köyü (SupplyChainVillage) olarak adlandırılmaktadır. $\mathrm{Bu}$ şekilde adlandırılması toplam alanın içerisinde 1 adet fabrika, 2 adet tedarikçi, 2 adet fason üretim tedarikçisi, 1 adet silobas lojistik tedarikçisi ve 1 adet de depolama lojistik tedarikçisi 
bulunmasından kaynaklanmaktadır. Hammadde ve ambalaj malzeme ( $\mathrm{Rm} / \mathrm{Pm} \mathrm{WH}$, RawmaterialPack materialwarehouse) deposu toplamda $9,720 \mathrm{~m}^{2}$ 'lik alan üzerinde 5,847 palet kapasitesiyle çalışan ve içerisinde 4 adet özel oda, 5 adet boşaltma kapısı, 7 adet rampa ve aralarda parmak rampalar (Fingerdock) bulunan bir depodur. Burada üretim öncesi (Inbound) lojistik gerçekleştirilmektedir. Depoda ekipman olarak 4 adet forklift, 6 adet reachtruck, 30 adet stacker ve el terminali, bir tane çekicisi olan arkasında vagonları bulunan ve iki kapısı olan tren benzeri araç (Milkrun) ve henüz yeni uygulamaya geçirilmiş 20 adet otomatik yönlendirmeli araç (AGV/ automedguiededvehicle) bulunmaktadır. Otomatik yönlendirmeli araçların (AGV) devreye girmesinin ardından tren benzeri çekici araçları (Milkrun) kullanımdan kaldırılması planlanmaktadır.

Depo içerisinde raf sistemi olarak sirt sırta (backtoback) raflar kullanılmaktadır. Hammadde ve ambalaj malzeme (RM/PM) deposunun dış yapısında boşaltma alanı (unloadingarea) ve bu alan da araçların yanaşmasına uygun olarak tasarlanmış rampalar bulunmaktadır. Deponun iç yapısında ise içerisinde sodyum Per karbonat gibi akışkan tozların bulunduğu temizlik ve kozmetik ürünlerinin özel depo alanları bulunmaktadır. Bu ürünlerin asitler ve parlayıcı maddeler gibi tutuşan malzemelerden ayrı olarak depolanması gerekmektedir. $\mathrm{Bu}$ kısımda üretim binası da bulunmaktadır.

Depo da ayrıca bitmiş ürün (FG/FinishedGoods), otomatik yükleme alanı bulunmaktadır. Bitmiş ürün sahasında 3 tane otomatik yükleme kapısı, 1 tane de olası bir arıza durumu için otomatik olmayan (manuel) yükleme kapısı bulunmaktadır. Bununla birlikte gitgide kullanımı düşen toz üretim binası da burada bulunmaktadır. Genel pazarda kullanımının oldukça düşmesi sebebiyle firmanın başı çeken ürünü likit üretim hattından sağlanmaktadır. Firmanın kurulduğu arazi içerisinde bir de tank çiftliği (tank farm) sıvı deposu bulunmaktadır. Tank çiftliği tesisleri, değişken konsantrasyonlardaki asit ve petrol gibi sıvıların üretiminde ve depolanmasında kullanılmaktadır. Firmanın bu sahada çalışan bir lojistik operatörü bulunmaktadır.

\section{Hammadde ve Ambalaj Malzeme (RM/PM) Deposu Çalışma Kapasitesi}

RM/PM deposuna ortalama günlük 45 tır giriş yapmaktadır ve 33 tanesi dökme yük (bulk) olarak gelmektedir. Depo içerisinde ortalama günlük 3600 palet hareket etmektedir. İndirme, bindirme, depoya alma ve üretime besleme hareketleri gerçekleştirilmektedir. Depo ortalama \%86 doluluk ile çalışmaktadır.

\section{Tank Çiftliği Operasyon Akıșı}

Tank çiftliği sahasına silolarla gelen ürünler tanklara bu sahaya aktarılmaktadır. Ürünün sağdan ve ileriden beslenmesinin ardından bitmiş hale gelen ürünler robotlarla paletlenmektedir. Daha sonra tankerlerde karışım formül oluşturulmaktadır. Oluşturulan karışım paketleme hattına gelerek şişelere otomatik dolumu sağlanmaktadır. Tüm bu işlemlerin bitmesiyle robotlar ürünleri kolilerden alıp belirli sayıda paletin üzerine dizmektedir. Paletlenmiş ürünler otomatik olarak streçle sarılıp hatta gönderilmektedir.

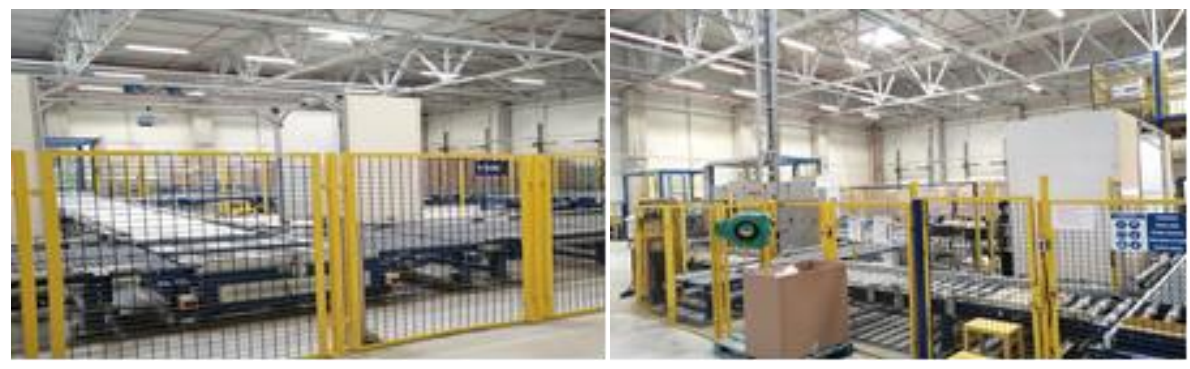

Resim 2. Bitmiş ürün hattı

Resim 3. Bitmiş ürün hattı, kod tarayıcı ve kilo kontrol kısmı 


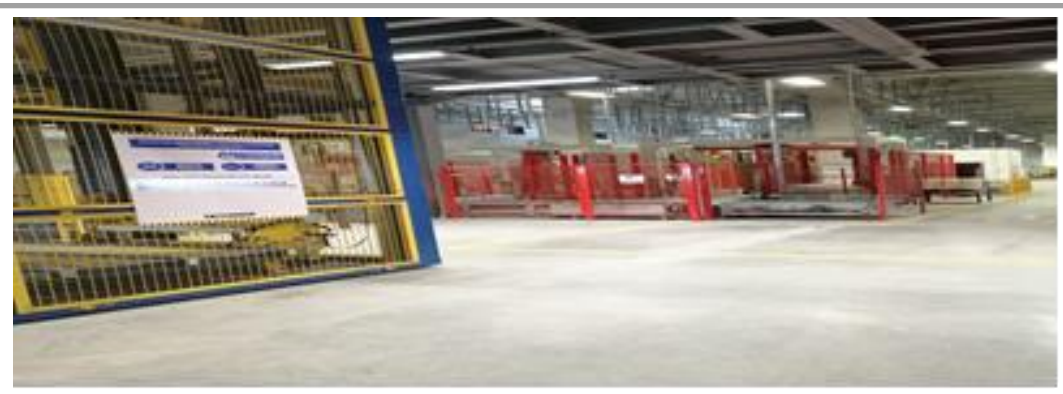

Resim 4. Bitmiş ürün sahası

Görsellerde görüldüğü gibi otomatik olarak bitmiş ürün (FG) yükleme alanında toz ve likit ürünler toplanmaktadır. Likit ürünler asansörle hatta bağlanmaktadır. Hat üzerinde otomatik ilerlemektedir. Likit hatlar kabin tarzı bir alana girerek kiloları ölçülmektedir. Likit ürünlerin toleransları bulunmaktadır. bu sebeple içerisinde eksik ya da fazla olup olmadığının kontrolü sağlanmaktadır. Bunlara ek olarak kolilerin üzerinde uluslararası bir (EAN/International ArticleNumberingAssociation) barkod bulunmaktadır. Hat üzerinde bulunan tarayıcılar (Scaner) barkodu okuyarak firmada kullanılan sisteme otomatik olarak girmektedir.

Firmada SAP (Systems Analysis and Program Development) yazılımı kullanılmaktadır. SAP sisteminde ilgili departmanın ara yüzünde tanımlı olan barkodun karşılaştırması yapılmaktadır. Her ürünün ana verisi (Master data) bulunmaktadır. Sistem uluslararas1 barkoda(EAN) karşılık gelen malzeme numarasını bulmaktadır. Örneğin 115-116 numaralı ürünü, ürün hakkındaki detaylarla, litre gibi, eşleşme sağlamaktadır. Son olarak ürünün kilosunda da sorun bulunmazsa geçişine izin verilmektedir. Ardından otomatik aplikatör, hat üzerinden devamlı gelen paletlere etiket yapıştırmaktadır. Daha sonra iki tane likit hattı için bir tane de toz için olan otomatik yükleme alanlarına paletler düşmektedir. Eğer herhangi bir etiket okuyamama problemi ya da ağırlık problemi oluşursa burada yeniden kontrol (Re-check) hattına düşerek tekrar kontrolü sağlanmaktadır. Hatası düzeltildikten sonra yeniden hatta beslenmektedir.

Sahada bulunan palet yükleme kapılarına araç gelmekte ve eğer paletlerin sayısı 32'ye ulaşmış ise yeşil ışık yanmaktadır. Yalnızca bu iş için tahsis edilmiş 6 tane araç bulunmaktadır. Bu araçlalar altında rulolar bulunan, içerisi zincirli olarak tasarlanmış fonksiyonel araçlardır. Araçlar yükleme alanına yanaştıklarında, araç üzerindeki otomatik butonlar aracın kilitlendiğinden emin olarak, elektrik akışını aktifleştirerek, elektrik bağlandığında araç içi ile üretim tarafının birbiri ile haberleşmesi sağlamaktadır. Eğer arka taraf işlem için uygun ise kapı açılmaktadır. Bariyerler indirilerek arkada bulunan konveyörlerin otomatik yükselmesinin ardından ürünler araç içine doğru akmaya başlamaktadır. İşlem tamamlandıktan sonra enerji akışı kesilmektedir. Enerji kesildiği için otomatik olarak konveyörler aşağıya düşmektedir. Olası bir hareket halinde konveyörlerin üzerindekiler dökülebileceği için kaza riski oluşturmaktadır bu sebeple aşağıya düşmektedir. Araç içine girmiş ürünler zincirin üzerine sabitlenerek hareketi engellenmektedir. Daha sonra bu araç ürünleri otomatik depolama ve alma sistemi (AS/RS) deposuna götürmektedir. Burada yapılan yükleme (Loading) işlemi aynı şekilde orada da boşaltma (Unloading) olarak yapılmaktadır. 


\begin{tabular}{lcccc} 
& Tablo 3: Bitmiş ürün yükleme alanı kapasiteleri ${ }^{1}$ & \\
\hline & $\begin{array}{c}\text { Günlük Palet } \\
\text { Miktarı }\end{array}$ & $\begin{array}{c}\text { Saatlik } \\
\text { Palet } \\
\text { Miktarı }\end{array}$ & $\begin{array}{c}\text { Tam } \\
\text { Kapasite } \\
\text { Çalışma } \\
\text { Miktarı }\end{array}$ & $\begin{array}{c}\text { Kapasite } \\
\text { Oranı (\%) }\end{array}$ \\
\hline $\begin{array}{l}\text { Maksimum } \\
\text { (Sene } \\
\text { başından } \\
\text { itibaren) }\end{array}$ & 3202 & 152 & 240 & $\% 64$ \\
\hline Ortalama & 2121 & 101 & 240 & $\% 42$ \\
\hline
\end{tabular}

Tablo 4: Bitmiș ürün yükleme alanı günlük sevkiyat kapasiteleri

\begin{tabular}{lc}
\hline Günlük Sevkiyat Kapasitesi & Tır Miktarı \\
\hline Maksimum & 100 adet \\
\hline Ortalama & 66 adet \\
\hline Ortalama Yarı Mamul & 8 adet \\
\hline
\end{tabular}

Ayrıca 2022 yılı için palet kapasitesi temel olarak toz ürünler için saatlik 90 palet, likit ürünler için saatlik 150 palet olmak üzere toplamda saatte 240 palet olarak öngörülmektedir.

\section{Faaliyetler Hakkında}

Üretim binasında forkliftlerle araçlardan boşaltma işlemi gerçekleştirilmektedir. Tren benzeri çekici araçlar (Milkrun) deterjanhatlarına giren şampuan ve krem gibi üretim hatlarını beslemektedir. Sahadaen çok hareket, şişede görülmektedir. Şişeler yakıt bölmesi (Bunker) aracılığ 1 ile doğrudan hattan aktarılmaktadır. Konveyörler direkt rampalara götürmektedir. Burada bulunan parmak rampaların özelliği yan kısımlardan da açıldığında palet alınabilmesini sağlanmaktadır.

Fabrikada temel olarak üretim öncesi (Inbound) lojistik yapılmaktadır. Üretim öncesi (Inbound) lojistik kısaca tedarik ve sevkiyat faaliyetlerini kapsamaktadır. Tedarikçiden hammaddeye, paketleme (pack) malzemelerin depolanması sağlanmaktadır. Sevkiyat kısmı üçüncü parti lojistik (Third party) tarafından sağlanmaktadır. Maliyet açısından belli bir ölçeğe çıkan firmalar bu tarz hizmetleri alanında uzman olanlardan dış kaynak kullanımı (Outsource) olarak sağlamaktadırlar. Hizmet satın aldıkları ' $\mathrm{X}$ ' lojistik firmasının ülkenin her yerinde özel şoförü bulunmaktadır. Örneğin ' $\mathrm{X}$ ' lojistik firması, bir firmanın malını getirirken, diğer bir firmanın da malını götürebilmektedir. Bu şekilde maliyeti çok daha ucuza getirebilmektedirler. Bunun tam tersi eğer sevkiyat hizmeti satın almaz ise $\mathrm{ABC}$ şirketi bir yere giderken boş gidip, gelirken dolu geleceği içi maliyet 2 katına çıkmaktadır. $A B C$ firmasının uzman olduğu iş, üretim gerçekleştirmektir. Ürettiği ürünü taşıma işini firma kendisi üstlenmemektedir. Dolayısıyla dışarıdan destek almaktadırlar. Ayrıca depolamasını gerçekleştirmektedirler. Üçüncü parti lojistik (3PL) malı tedarikçilerden doğrudan çekebilmektedirler. ABC bir kimyasal firması olduğu için, silobaslarla, bir taraftan hava basılan diğer taraftan hava üfürülen dorseler ile, sıvı ve toz ürünler taşınmaktadır. Tehlikeli kimyasal ürünlerde bulunmaktadır.

${ }^{1} 2018$ senesinin başlangıcından itibaren. 


\section{Ekipman Maliyetleri ve Özellikleri}

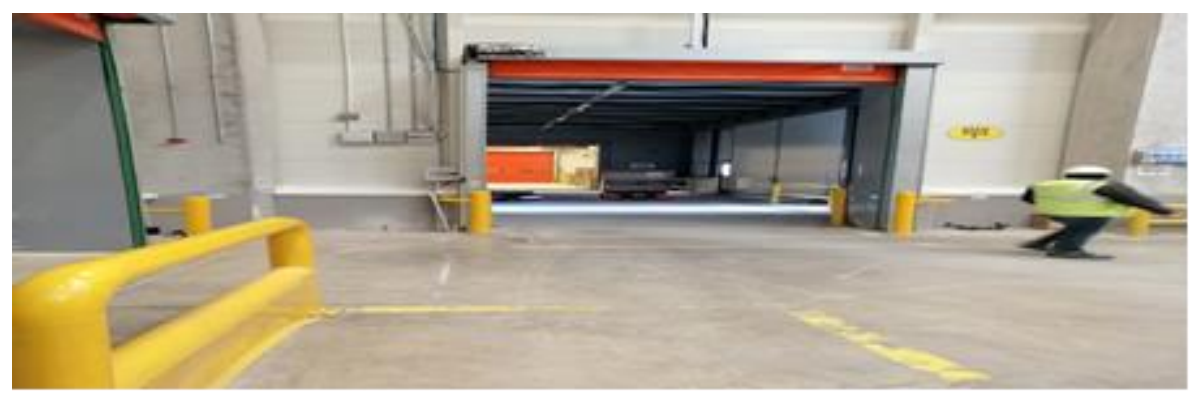

Resim 5.Forklift

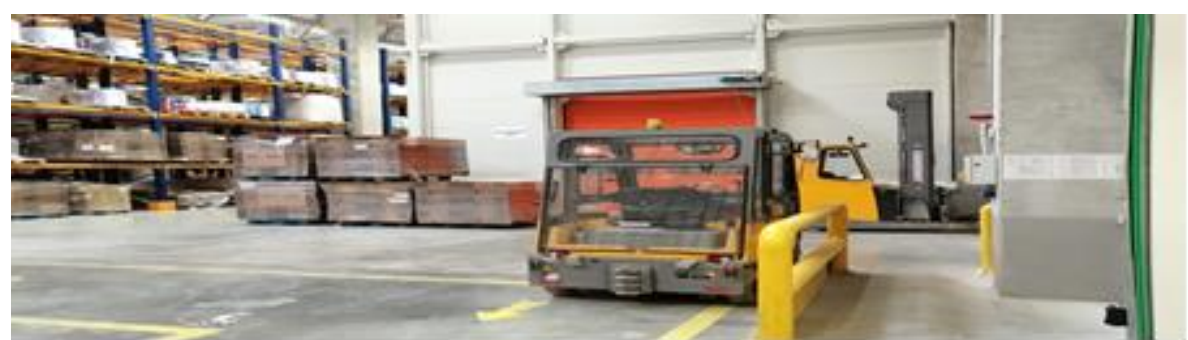

Resim 6. Otomatik yönlendirmeli araç (AGV)

Ekipmanlarının tamamı kiralanmaktadır, öz mal alarak çalışmamaktadırlar. Görselde sağ tarafta kırmızı 1şıkları yanık halde bulunan otomatik yönlendirmeli araç (AGV) ürün taşımaktadır. Sol tarafta beyaz 1şıkları yanık halde olan otomatik yönlendirmeli araç (AGV) ürün bırakarak ve geri dönmektedir. Sensörleri sayesinde birbirlerini algılayabilmektedirler. Otomatik yönlendirmeli araçların (AGV) bir tanesi 25 Bin Dolardır. Otomatik yönlendirmeli araçların (AGV) maliyeti yüksek gibi gözükse de iki-üç tane forkliftin yaptığı işi otomatik yönlendirmeli araç (AGV) tek başına yapabilmektedir ve molaya ihtiyaç duymamaktadır. Forklift kullanıldığında bir de operatör çalışı

Elektrikli forkliftlerin bir tanesinin fiyatı ise 100 Bin Euro'dur. Firmada dizel forklift kullanılması yasaktır. Elektrikli forklift kullanılmaktadır. İstif makinaları (Reachtruck) dar alanlarda çalışabilmektedir.

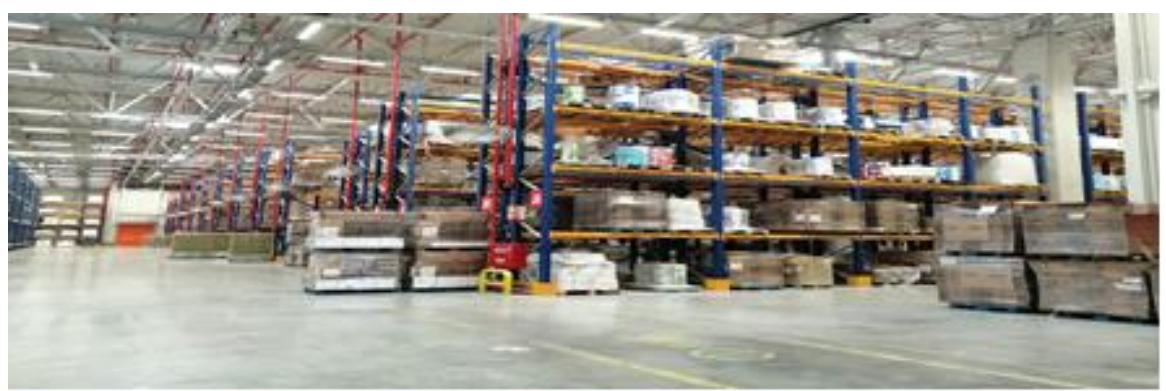

Resim 7. Kayar raf sistemi 


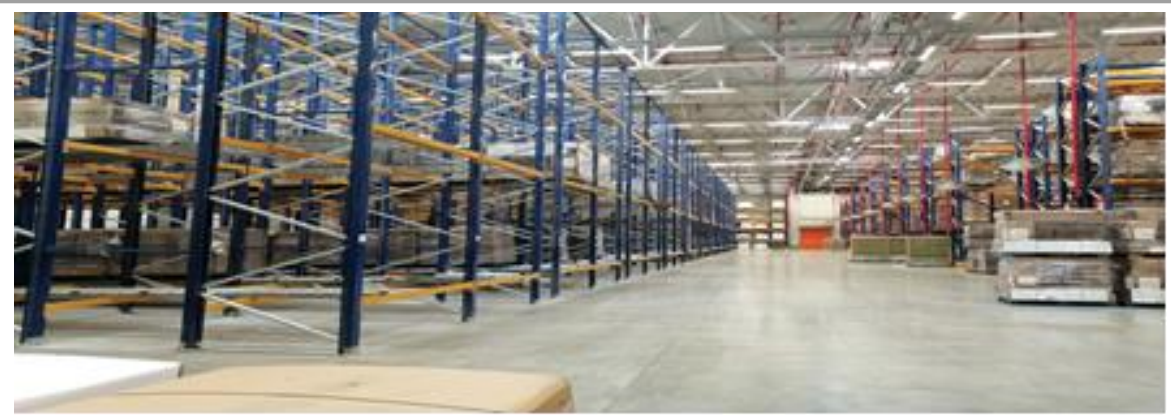

Resim 8. Surt sırta raf sistemi

Resim-8'de görülmekte olan sirt sirta (backtoback) raflar hammadde ve ambalaj malzeme (RM/PM) deposunda, palet koymak için kullanılmaktadır. Resim-7'de görüldüğü gibi aynı zamanda kayar raflar da bulunmaktadır. Bu raf sitemi herhangi bir enerji harcamadan, eğimden yararlanarak kendi kendine paletlere hareket kabiliyeti kazandırmaktadır. Arka kısmı eğimli, üzerinde rulolar bulunmaktadır. Hem hareket maliyetini sıfıra indirerek hem de ilk giren ilk çıkar prensibini (FIFO) yüzde yüz sağlamaktadır. Çünkü bir taraftan beslerken, bir taraftan kullanılmaktadır. Bu prensipte en eski ürün ilk çıkmaktadır.

Otomatik yönlendirmeli araç (AGV) projesinden dolayı boydan boya kayar raf sistemi kullanılmaktadır. Kayar rafların arkasında da otomatik yönlendirmeli araçlar (AGV) bulunmaktadır. Orada da istasyonlar bulunmaktadır. Küçük parçalar halinde o istasyonlar beslenmekte daha sonra otomatik yönlendirmeli araçlar(AGV) onları alıp hattın içerisinde yerleştirmektedir. Ürünleri ilgili yere götürüp teslim etmektedir.

Deponun bir tarafında rampalar bulunmaktadır, araçlar yanaşarak ve ürünleri sırt sırta raflara dizmektedirler. Yanıcı ve patlayıcı maddeler için, parfüm gibi, özel depolar bulunmaktadır. $\mathrm{Bu}$ kısımlara özel olarak havalandırma sistemleri kurulmaktadır. Spesifik ürünler için özelliklerine göre cep depolar oluşturulmaktadır. Genel depoda koli, kapak ve plastik ürünler bulunmaktadır. Bu kısımda yalnızca hammadde ve paketleme yapılmaktadır.

Bitmiş mamuller, yine otomatik bir sistemde otomatik araçlara yüklenmektedir. Burada sistem tamamen otomatik işlemektedir. Bitmiş ürünler önce konveyörlere gelerek sonra aracın içerisine yerleştirilmektedir. Araç otomatik olarak kapıya yanaşmaktadır, kapı otomatik olarak açılmakta ve paletler tırın içerisine kayarak girmektedir. Yan kısımda bulunan otomatik depolama ve alma sistemi (AS/RS) deposuna gitmektedir. Otomatik depolama ve alma sistemi (AS/RS) deposu tamamen otomatik bir depodur. Orada da yine aynı sistem bulunmaktadır. Sırasıyla araç kilitlenmekte, kapı açılmakta ve mallar otomatik olarak boşaltılmaktadır. Her paletin üzerinde barkodlar bulunmaktadır. Daha sonra bu barkodlarda kimlik numaraları (ID) bulunmaktadır. Bu kimlik numaralarını (ID) sistem sensörlerle okuyarak onları alıp depoya götürmektedir. Depo yaklaşık 45 bin paletlik kapasitededir. Burada 20-25 metre civarında vinçler (Crane) kullanılmaktadır. Siparişler otomatik olarak girilmektedir. Örneğin bir market zincirinden sipariş̧ gelmekte ve sipariş sisteme girildiğinde, ona uygun paletler otomatik vinçler ile toplanmakta ve hatta verilmektedir. Bu hattın başında araçlar bulunmakta ve yine operatör kontrol etmektedir. Kontrolün ardından yüklenmektedir.

Barkod ve karekod uygulamaları bulunmaktadır. Örneğin karekod uygulamasını likit ürünlerde kullanmaktadırlar. Şişeler silobas ya da izo tankerlerle gelmektedir. Ürünlerin maliyeti çok yüksektir. Yaklaşık bir tanker ürün 160-170 bin TL' ye kadar çıkabilmektedir. Temelde bu ikinci maliyeti oluşturmaktadır. Birinci maliyet ürün yanlış tanka basıldığ 1 takdirde oluşmakta ve tüm ürün zarara uğramaktadır. Bundan dolayı karekod sistemi kullanılmaktadır.

Tank sahasında da bir operatör bulunmakta ve işlemleri o yürütmektedir. Tank sahasında hata yapılmasını engellemek için tedarikçi irsalenin arkasına bir karekod yazdırılmaktadır. Karekod 
tamamen ürünün malzeme numarasını (SQ) ve tedarikçisini içeren bilgileri içermektedir. Ayrıca bir tane de pompanın üzerine yapıştırılmaktadır. Operatör el terminali ile ikisini de okutarak eşleştirmektedir. Ve eşleşme sağlandıktan sonra pompa otomatik devreye girmektedir. Böyle olas1 hataları ve hatalardan doğacak yüksek maliyetlerin önüne geçilmektedir.

\section{Karar Destek Sistemleri}

Firmada tamamen SAP (Sistem analizi ve Program Geliştirme)sistemi kullanılmaktadır. SAP dünyada en çok kullanılan kurumsal kaynak planlaması (ERP) olan Alman menşeili programdir. Kurumsal firmalar \%70 oranında bunu yazılımı tercih etmektedir. $\mathrm{Bu}$ program sayesinde herkes her şeyi eşitleyebilmektedir. Örneğin buradan personel bir ürünün ismini değiştirdiğinde ürünün fiyatı diğer tarafta $10 \mathrm{TL}$ gözükmekte ancak buradaki $100 \mathrm{TL}$ maliyet de eşleşmemektedir. Dolayısıyla finans departmanı artışı görmektedir. Bu sistem sayesinde her şeyin karşılığ1 anında buradan görülebilmektedir. Daha kompleks, esnek ve depo için özel olmas1 istendiğinde yazılım özel olarak dışarıdan kullanılmaktadır. Cubic, Wms, Lv3 (Depo yönetim sistemi) ve Axapta gibi takip ve yönetim sistemleribunlara örnek verilmektedir.

Verilerin hepsi SAP' den alınmaktadır. SAP' nin depo yönetim (WM/Warehousemanagement) modülü kullanılmaktadır. Bu modül malzemelerin depo içerisinde takibinin yapılmasını sağlamaktadır. Malzemenin hangi rafta bulunduğu ve rafın tam olarak neresinde bulunduğu gibi bilgiler öğrenilebilmektedir. Daha sonra depolamada ve depodan malzemenin ayrılışında gerçekleşen işlemler için öneriler sunmaktadır. Burada da bu önerileri malzeme hareketinden kaynaklanan verilerden alarak yapmaktadır. $\mathrm{Bu}$ öneriler malzemenin ilk girişi, iadesi, stok hareketleri gibi bilgilerle yapılmaktadır. Aynı zamanda kullanılan barkod sistemine ve el terminallerine bağlantılı olarak çalışmaktadır. Yapılan işler için zaman tahmini sunarak, teslimatlar buradan takip edilmekte ve adresleme özelliği bulunmaktadır. Depo planlamasını ve bu kararların alınmasını da sağlamaktadır. Satın alınacak malzemelerin kararı da bu şekilde alınmaktadır. Satın alınacak ürünün onayı alındıktan sonra depoya yeni girecek malzemenin bilgileri girilmekte ve depoya ne zaman girdiği, hangi depoya girdiği, girişini kimin yaptığı ve bunların maliyeti sistemde bulunmaktadır.

Firmada Excel gibi ticari ofis yazılım programları (Office) da kullanılmaktadır. Araç giriş çıkış bilgileri, kaç tane olduğu gibi bilgilerin hepsini SAP sisteminden alınarak daha sonra zaman etütleri ile daha önce bahsedilen işlerin süreleri ölçülmektedir. Kaç tane personel ihtiyacı var, kaç tane makine ihtiyacı var gibi soruların cevabı bütün bunların sonucunda alınmaktadır. Örneğin otomatik yönlendirmeli araçların (AGV) miktarı da bu verilere kullanılarak belirlenmektedir.

Ayrıca bitmiş ürün (FG) tarafında 'Cubic' (Depo yönetim sistemi) kullanılmaktadır. Adlandırmasını kendileri yaptıkları kurum içi bilgi paylaşım sistemi olan 'FOL' (Fabrica online) adında bir programlamaları bulunmaktadır. Kendi ağını kullandığı ve raporlamaları çıkarttığı bir sistemdir. SAP belirli bir kalıpta olduğu için kendilerine bazı esneklikler oluşturmak amacı ile bunu kullanmaktadırlar. AGV nin çalışma hareketlerinin tamamı kurum içi bilgi paylaşım sisteminde 'FOL' de yapılmaktadır. SAP sistemi Hindistan'dan yönetildiği ve şirketin IT merkezi de orada bulunduğu için bunları uyarlamak çok maliyetli ve dışarıdan destek gerekmektedir. $\mathrm{Bu}$ yüzden sistemi komple baştan sona yenilemek gerekmektedir. Dolayısıyla kurum içi bilgi paylaşım sistemi`FOL' üzerinden istediklerini gerçekleştirebilmekte ve yine de SAP sistemi ile bağlantılı olarak hattan gelen paletlerin bilgileri buradan alınmaktadır.

Stok hesaplamaları ise aylık ve yıllık olarak gerçekleştirilmektedir. Yıl sonu stoklarına bakılarak yıllık stok devir hızları hesaplanmaktadır. Bir stok kaç günde devretmektedir ve kaç gün olması gerekmektedir bunların hesaplanması yapılmaktadır. Minimuma indirilmesi gerektiği için iyileştirme çalışmaları yapılmaktadır. 


\section{Ar-Ge Çalışmaları}

Firmanın Ar-Ge çalışmaları için İstanbul'da bir ekibi bulunmaktadır. Ama yeni ürünün üretimi çoğunlukla sahadan talebe göre gelmektedir. Otomotiv sektörü için bu durum daha farklı gelişmektedir ve kendi içinden bir şeyler üretilmektedir. Bu sektör daha çok sahadan bilgileri alarak ilerlemektedir. Örneğin kullanıcılar şikâyette bulunduğunda bu şikayetlere dayanarak ürün üzerinde karar alınmaktadır. Firmanın şu an çevre ile ilgili yeni bir projeleri bulunmaktadır. Firmanın en güçlü x ürünüdür. Ama bu x ürününün normalde \%90'1 sudan oluşmaktadır ve bu ürün taşınmaktadır. Düşünüldüğü takdirde tırlarla su taşıması yapılmakta ve bu ciddi boyutta zar oluşturmaktadır. $\mathrm{Bu} \quad \mathrm{x}$ ürününün konsantre hali planlanmaktadır. Deneme aşaması gerçekleştirilmiştir. Kullanıcıların bu ürünü kendileri suyun içerisine karıştırabilecekleri formda üretilmesi planlanmaktadır. Bu sayede o kadar ürün tırlarla taşınmasının önlenmesi bununla birlikte personelin gereksiz yol kat etmesinin de önlenmesi beklenmektedir. Dolayısıyla çevreye karbondioksit salınımının azalması öngörülmektedir. Böylelikle 10 birim hareketten 1 birim harekete düşmektedir. Ciddi boyutta tasarruf sağlanarak çevreye verilen zarar oranının düşürülmesi hedeflenmektedir. Ayrıca üretim maliyetlerini düşürmektedir.

Gelecek ile ilgili şirketlerin su tüketimini azaltmaya yönelik hedefleri bulunmaktadır ve bu üründe de ciddi su tüketimi olduğu için bu çalışmalar yapılmaktadır. 'ABC' şirketinin de bu şekilde birçok sosyal amacı bulunmaktadır. Su tüketimini azaltmak, plastik kullanım oranını düşürmek, paketleme de tamamen yeniden işlenebilir kâğıt kullanmak gibi küresel hedefleri bulunmaktadır. Tüm bu beklentiler dahilinde Ar-Ge ekibi yeni ürün tasarımlarını yapmaktadır. Ar-Ge ekibi tasarladıktan sonra yukarıda bahsedilen süreçlerden, verilerden faydalanılmaktadır. Fizibilite çalışmaları yapılmaktadır. Sonra saha da karşılığı olup olmadığa sorularına cevap aranmaktadır. Daha sonra reklam ve pazarlama tarafinda ne kadar reklama ihtiyaç olduğuna kadar giderin oluşmasının beklendiği gibi sorular bütün bu çalışmalarla yanıt bulmaktadır. Sonra da tesisler de bunların denemeleri yapılmaktadır. Denemeler başarılı olduktan sonra tedarikçilerle görüşülerek ürünler belirlenmekte ve üretim tarihi kararlaştırılarak üretime başlanmaktadır.

\section{Geri Bildirim Mekanizması}

Sosyal medyada 'ABC' şirketinin markalarını tarayan bir sistem bulunmaktadır. Bu şirket markaları internette ne kadar tıklandı ne kadar konuşuldu ne kadar olumlu ne kadar olumsuz yorum var bunlar takip edilmektedir. Ayrıca müşteri şikâyet platformu da bulunmaktadır. Kalite departmanı bunları incelemektedir. Ama sosyal medyada daha gelişmiş yöntemler bulunmakta ve sosyal medya kanalı üzerinden daha rahat geri dönüş sağlanabilmektedir. Örnek vermek gerekirse geçtiğimiz hafta şirketin kalite günü olduğu için güzel yorumlar alınarak sunumlar yapılmaktadır. Kötü ve olumsuz yorumlara karşı da böylece hemen aksiyon alınabilmektedir. Tedarik kısmında hatta kadar, hattın neresinde, ne eksik var bunların bulunması en fazla 2 gün sürmektedir.

\section{Dijital Uygulamalar}

Firmada el terminalleri kullanılmaktadır. El terminallerinde de SAP 'nin mobil uygulamas1 bulunmaktadır. Tablet kullanılan noktalar olmaktadır. Orta ve küçük ölçekli firmalar bu programı çok fazla tercih etmemektedirler. Maliyeti çok yüksek olduğundan dolayı gerçekten ihtiyaç olduğu takdirde kullanılması gerekmektedir. Fakat 'ABC' şirketi gibi büyük şirketlerde ilk yatırım maliyeti yüksek olsa da sürekli maliyeti düşük olduğu için tercih edilmektedir. Bu durumda getirisi götürdüğünden çok daha fazla olduğu için tercih edilebilmektedir. Orta ölçekli firmalar küçük birkaç paket program yapmakta ve her kısım için ayrı olarak kullanmaktadır. Sonra bir kişi tüm bu verileri alıp Excel'de maliyet hesaplaması yapabilmektedir. Bu durumun olumsuz olmadığı düşünüldügünde, sonuca bakıldığı takdirde maliyet olarak daha mantıklı ise o firma için iyi bir seçenek olmaktadır. 


\section{Uygulamaların İşletme Fonksiyonlarına Etkisi}

Bu teknolojik uygulamalar 'ABC' şirketine hız kazandırmaktadır. Daha önce bahsedildiği gibi bu sayede dört beş farklı programdan ayrıca bir işlem yapmak zorunda kalınmamaktadır. Hata oranında ciddi anlamda azalma görülmektedir. Herhangi bir elle işlem yapılmamaktadır. Sonuçta farklı programlar bir araya getirilip bir hesaplama yapıldığı takdirde yapan kişi verileri girerken hatalı tuşlama yapar ise veriler tamamen farklı bir boyut kazanabilmektedir. Bu tarz hataların önüne geçilmiş olunmaktadır. Bu programda herhangi bir hata yapıldığında, program bunu fark edebilmektedir. SAP 'nin kullanışlı özelliklerinden birisi, örneğin üretim için 100 palet x ürününe teyit verildiğinde, program bir başka tarafta ürün ağacına (BOM) göre bu miktarın kontrolünü sağlayarak tüketilen miktarla eşleştirmektedir. Eşleşme sağlanmadığı takdirde sistem uyarı vermektedir.

Diğer bir yandan izlenebilirliği artırmaktadır. İzlenebilirlikten kastedilen müşteriden bir şikâyet geldiğinde anında ürün tespiti yapılarak, müşteri tespit edilmesidir. Üzerinde yeniden kontrol (Re-check) hattında yazılmış tarih ve hat numarası bilgileri bulunmaktadır. Bu bilgilerden ürünün hangi sevkiyatta çıktığına, hangi palette olduğuna bakılmaktadır. Palet numarasından hangi gün üretilmiş, hangi hatta üretilmiş, içinde hangi koli var bunlara bakılmaktadır. Geriye dönüp o üretimde hangi hammadde kullanılmış, o hammadde depoya hangi tedarikçiden gelmiş, ne zaman gelmiş, hangi araçla gelmiş tüm bu bilgiler ilk noktasına kadar takip edilebilmektedir. Sonra örneğin ' $y$ ' tarihinde üretilen ' $x$ ' üründen dolayı yaşanan hataların müşteriye nasıl yansıdığı ile ilgili geriye dönük izlenebilirlik sağlanabilmektedir. Denetim açısından bu nokta çok önemli bulunmaktadır.

\section{Satış Kararları}

Satış kararlarını alma noktasında da yine SAP devreye girmektedir. Ürünlerin son kullanım tarihi (SKT) ve her ürün için distribütöre çıkış zamanları bulunmaktadır. Örneğin ' $x$ ' ürününün son kullanma tarihine 1 yıl kaldığında ve müşteriye çıkış zamanı geldiğinde son 6 ay kalmış ise müşteriye çıkışına izin verilmemektedir. Bu tarz bir sistemi bulunmaktadır. Böyle ürünler fabrikalarda satış noktalarında hızlı tüketilebileceğinden dolayı anında kullanıcıyla buluşabilmektedir. Ya da ürünün son kullanma tarihine 1-2 ayın altında kalmış ise tamamen bloke edilip imhaya gönderilmektedir.

\section{Lojistik İş Süreçleri}

Firmada depolama, mal kabul, üretim besleme, (Internal lojistik), çıkış ve yeniden depolama (Bitmiş ürün olarak depolama), yükleme ve sevkiyat gibi lojistik süreçler bulunmaktadır. Firmanın bu lokasyonunda lojistik direktörlüğü ve müşteri hizmetleri departmanı bulunmaktadır. Buradaki müssteri hizmetleri, müşteriye giden gelen araçların organizasyonunda oluşan problemleri çözme işi ile ilgilenmektedirler. Hammadde ve ambalaj malzeme (RM/PM) deposu için tedarikçiden hammadde malzeme çekme süreci gerçekleştirilmektedir. Bitmiş ürün (FG/Finishedgoods) kısmı için ayrıca süreçler bulunmaktadır. Bir de ayrıca 'ABC' şirketinin Gebze'de de bir depoları bulunmaktadır. Gebze lokasyonundaki depo, akıllı depo olmamakla birlikte orada da bitmiş ürün stoklanmaktadır. Bir de ' $x$ ' lojistik firmasının nakliye araçlarının tedarikçilerini yöneten bir ekip bulunmaktadır. Ayrıca doğrudan dağıtım (Direct distribution) müdürlüğü bulunmaktadır. Bu kısımlar şirketin cep depoları (İstanbul, İzmit, Ankara gibi yerlerde, yaklaşık 300-500 $\mathrm{m}^{2}$ lik) olarak belirtilmektedir. Buralardan ürünler paketlenerek, küçük kuryelerle müşteriye gönderilmektedir. Şirket için çok fazla kar getirisi olmamaktadır.

Gelecekte müşteri ihtiyaçları geliştirildiğinde, market ve mağazalar aradan çekildiğinde direk firmanın üretim hattından ürün satın alınacağı öngörülmektedir. Otomotiv ve beyaz eşya gibi ciddi pahalı ürünleri olan sektörlerde montaj hattında bu kısım çok önemli olmaktadır bunun sebebi ise orada sadece bir vida eksikliğinden bile tüm hat durabilmekte ve bir araç 1-2 ay gecikebilmektedir. Aksatmamak için tonlarca vidayı stoklamak, her hat için düşünüldüğünde 
milyonlarca doları depolamak anlamına gelmektedir ve bunlar stok maliyeti oluşturmaktadır. Stok maliyeti ise paranın piyasaya göre değer kaybetmesi olarak görülmektedir. Örneğin firma stok koyduğu takdirde, örneğin ' $\mathrm{ABC}$ ' şirketinin belirli bir miktarın üzerine çıkmamak gibi bazı hedefleri bulunmaktadır, sonuçta bu miktar piyasada yatırım olarak kullanıldığı takdirde şirketin başka kazançlar sağlayabilme imkânı olabilmektedir ya da diğer fabrikalarına verip oradaki nakit ihtiyacını karşılayarak pek çok zarardan kurtulabilmektedir. Stok maliyeti kısaca paranın durduğu yerde kaybettiği değer olarak tanımlanmaktadır. Ayrıca şirket risk de alarak, bir sürü malı çekiyor ve o üretim durmuş oluyor ve eğer vazgeçilirse o stok arkada kalmaktadır (Inback). Dolayısıyla her zaman stoksuz ya da en az stokla çalışmak hedeflenmektedir.

İç (Internal) lojistik bu noktada çok önem kazanmaktadır. Şirketin hattı ne zaman ve ne kadar hızla beslemesi gerektiğine bunlara bakılarak karar verilmektedir. Tam zamanında üretim (JIT/ Just in time) felsefesine ne kadar uygun besleme yapılırsa şirket için o kadar başarı kaydedilmemektedir. Şirketin anahtar kararları bunun üzerine kurulmaktadır. Örneğin üretimde duruş sebepleri kaydedilmektedir. Hattın neden durduğu ve genel ekipman etkinliği (Oee/ Overalequipmenteffectiveness) kaydı tutulmaktadır. Toplam ekipman etkinliğini hesaplanmaktadır. Bunun \%100'e yakın olması en iyi sonuç olarak görülmektedir. \%60-70'lerde ise kalan kısmının neden kaybedildiğine dair raporlaması devamlı yapılarak çözüme kavuşturulmaktadır. Kısım kısım üretim hatası ve malzeme eksikliği gibi tespitler yapılmaktadır. Bunların da hangi departmandan kaynaklandığına bakılmaktadır. Sonra ilgili departmana bildirilmektedir. Zarar miktarı hesaplanarak ve departman yetkilileri konuyla ilgili rapor vermektedir. Y1l sonunda buna göre anahtar performans göstergesi (KPI) belirlenmektedir. Bölüm hedefleri belirlenerek onlara göre takibat yürütülmektedir. Anahtar performans göstergesi (KPI) aynı zamanda şirketin odak noktasını göstermektedir.

\section{Sistem Entegrasyonu}

Şirketin bu lokasyonunda şişe tedarikçileri hemen yakınlarında bulunmaktadır. $\mathrm{Bu}$ tedarikçilerde 'ABC' şirketi gibi büyük şirketlerdir. Tedarikçi firmaların üretimleri ile ' $\mathrm{ABC}$ ' şirketinin sistemi arasında çevrimiçi takip sistemi bulunmaktadır. Tedarikçi firmanın stokları doğrudan 'ABC' şirketinin SAP sistemine aktarılmaktadır. 'ABC' şirketinin üretim planları da bütünleşmiş bir şekilde tedarikçi firmanın sistemine aktarılmaktadır. ' $\mathrm{ABC}$ ' şirketinin üretim planına göre öncelikler belirlenmektedir. Üretilen ürünlerin çekme işlemini 'ABC' şirketi adına aracı lojistik firması yapmaktadır.

Yine şirket adına silobas sürecini farklı bir lojistik firması tedarikçilerden akış sağlamaktadır. Silobas sürecini yürüten lojistik firmasının kendi tesisi bulunmaktadır. Silobasla taşınan maddelerin bazıları belirli bir sıcaklıkta olması gerektiği için 1sıtılmaktadır. Bu hazırlanan kısım için 'ABC' şirketinin ayrıca tankları bulunmaktadır. Tankların seviyesini ölçen yük hücresi (Loadcelller) ile tankın ağırlığı ölçülmekte ve o ağırlığa göre içerisinde kaç litre olduğu hesaplanmaktadır. Şirketin kurum içi bilgi paylaşım sisteminde (FOL) kendi tanklarının doluluk seviyeleri görülmektedir. O göstergeler aynı zamanda silobas kısmı ile ilgilenen lojistik firmasının da sistemine aktarılmaktadır. Silobas kısmı ile ilgilenen lojistik firması 'ABC' firmasının tank seviyelerine göre elindeki stoku şirkete göndermektedir.

Müşteri tarafında satış ekiplerinin kullandığı elektronik veri değişimi (EDI) diye adlandırılan küçük bir sistem bulunmaktadır. Orada sahadaki personel müşteri siparişini el terminalinden girmekte ve yazdığı üretim departmanının sistemine düşmektedir.

\section{Lojistik Faaliyetlerde Kullanılan Teknolojiler}

Firmanın soğuk depo kısmında buzdolabı (Frigo) diye adlandırılan araçların içerisinde mobil küresel iletişim sistemi (GSM) kartı gibi kartlar bulunmaktadır. O kartlar sayesinde 7/24 hem konumu hem içerisindeki sıcaklığı çevrimiçi takip edilebilmektedir. Bu şirket için kritik bir nokta 
olmaktadır. Aynı şekilde şirketin soğuk depolarının sıcaklığı da bu şekilde takip edilmektedir. Bütün bunlar yine kurum içi bilgi paylaşım sisteminde (FOL) gerçekleşmektedir.

Otomatik depolama ve alma sistemi (AS/RS, Automated Storage andRetrievalSystem) tarafında tüm araçların kimlik kartı numaraları (ID) bulunmaktadır. Kimlik kartı numaralarına (ID) göre takip yapılabilmektedir. Ancak oradaki araçlar şirketin kendi öz araçları olmadığı için tamamen takip sağlanamamaktadır yani yolda tam olarak nerede olduğunu şirket takip edememektedir. Sadece bir kısmını takip edebilmektedirler. Lojistik firmaları da çoğunlukla öz mal olarak aldığı araç sayısı komisyonla iş yaptığı araç sayısından az olmaktadır. Dolayısıyla araç takip sistemi çok gerçekçi bir sistem gibi durmamaktadır. Şirket içerisinde yalnızca birkaç tane aracın takibi yapılmaktadır. Yine de şirket araçları, tedarikçi üzerinden irsaliye numarası ile araca şirket tarafından verilen nakliye numarası ile kontrol sağlamaktadırlar, yani izlenebilirliğini takip edebilmektedirler. Anlık takip olarak yapılmamaktadır. Şirket şu anda buna ihtiyaç duymamaktadır. Belki bu bir kargo şirketi için önemli olabilir ancak 'ABC' şirketi hali hazırda bunu başka bir firmadan dış kaynak kullanımı ile sağladığı için bilgileri de bu firmadan raporlar halinde almaktadır.

Şirket radyo frekanslı tanımla teknolojisi (RFID) sistemini içerideki 6 tane delikli araçta kullanmaktadırlar. Şirket gelecekte bunu arttırmayı ve tüm tedarikçiler arasında kullanmayı planlamaktadır. Barkod, karekod ve RFID de tüm bunları son teknolojisi olarak bilinmektedir. Karekod 'da tamamen görmesi, taraması ve bir tarayıcıdan (Scanner) okutması gerekmektedir. Radyo frekanslı tanımlama teknolojisinin (RFID) sisteme faydası, herhangi bir şekilde görmesine gerek kalmamasıdır. Anten alanına girdiğinde oradaki tüm bilgileri alabilmektedir. Şirket bununla ilgili projeler gerçekleştirmektedir. Sabit palet kullanmayı hedeflemektedir. Plastik paletlerin altına radyo frekanslı tanımlama teknolojisi (RFID) etiketi yapıştırılmasını planlanmaktadır. $\mathrm{Bu}$ halihazırda şirketin projeleri arasında yer almaktadır. Gelecekte radyo frekanslı tanımlama teknolojisi (RFID) etiketi sayesinde kimsenin barkod ve etiket kullanmaması öngörülmektedir. Örneğin 'ABC' şirketinin operatörü ürünü okutmasına gerek kalmaması beklenmektedir. Tıpk1 havalimanlarındaki gibi bir kapı konulması planlanmakta ve oradan ürün geçtiği zaman bir kapı, yüklendi bilgisi girerken diğer kapıdan geçerken aldığının bilgisini girerek ve sisteme bilgiler düşmesi planlanmaktadır. Şirket şimdi barkod kullanmaktadır. Ürün yüklenirken barkodları basılmaktadır. Şirket üretim departmanında aldığında tek tek okutmaktadır. Daha sonra sisteme işlemektedirler. Likitlerde ise tanklarla kantarlardaki ağırlığa ve seviye ölçerlere göre takip yapılmaktadır. Onlarda barkod kullanılamamaktadır.

Otomatik depolama ve alma sistemi (AS/RS) deposunda rampa rezervasyon sistemi kullanılmaktadır. Hangi aracın hangi rampaya yanaşacağının ile ilgili rezervasyon araca özel olarak yapılmaktadır. Her gelen araç nereye geleceğini bilerek gelmektedir. Bitmiş ürün (FG) tarafinda da sistem aynı şekilde işlemektedir. Ama hepsi aynı olduğu için araca özel rezervasyon yapılmamaktadır. Tedarikçiden gelen araçlardan teslim gerçekleştirildiğinde, onlar güvenliğe geldikleri zaman kendi kayıtları yaptırmaktadır. Aracın geldiğine dair bilgi kurum içi bilgi paylaşım sistemindeki (FOL) araç takip sistemine düşerek, araçlarını bekleme alanına çekilmesi ile ilgili bilgi mesajı gönderilmekte ve zamanı geldiğinde tekrar otomatik bilgi mesajı gönderilmektedir. Sonra içerideki personel takip edilmektedir. Üretim sırasına göre çağırılmaktadırlar. Tüm bunlar da otomatik mesaj yolu ile gerçekleştirilmektedir.

Piyasa araçlarında, araç konumu ve durumu hakkında bilgi alınamaması; şirketin sürücülerin olan teknolojiyi kullanmaya eğilim göstermemesi gibi sorunlarla karşılaşmasına sebep olmaktadır. Coğrafi bilgi sistemleri olarak kiralık araçlarda 'Arvento', piyasa araçlarında 'Fourkites' takip sistemleri kullanılmaktadır. Rota optimizasyon çözümleri için ise servis, maliyet ve çalışma prensipleri dahilinde çevrimiçi planlama sistemi kullanılmaktadır. Kendi kiralık araç sistemi olan firmalarda veri, araç takip cihazları ile sağlanabilmektedir; fakat burada da maliyet etkisi artmaktadır. 


\section{Optimizasyon Çözümleri}

Şirket optimizasyon çözümleri için de SAP modüllerini kullanmaktadır. Optimizasyon çözümü olarak stok düşürme hedefi belirlenmektedir. Ekonomik sipariş miktarı (Economicorderquantity) hesaplanmaktadır. Hesaplama sonucunda tedarikçinin sipariş almak isteği birim miktarı ile satın alma departmanının hesapladığı birim maliyeti ile kıyaslanmaktadır böylece maliyetin düşürülmesi sağlanmaktadır. Burada iki departmanın hesapladığı birim miktarları arasında optimizasyon hesabı yapılmaktadır. Hem tedarikçi ile pazarlık yapılmakta hem de stok sinırları hesaplanmaktadır. Sonra birim sayısı optimum düzeyde belirlenmektedir. Bütün bunları hali hazırda sistem otomatik hesaplamaktadır. Burada toplam maliyet hesaplanmaktadır. Eğer bunlar birbirine entegre olmamıș olsaydı örneği satın alma kendine göre çok iyi tasarruf yaptığını düşünmekte iken diğer tarafta stokta yaptığı zarar çok daha fazla olabilmektedir ya da fazla mesai yapılmış olabilir ya da depo kapasitesi aşıldığı için dışarıya depolama ücreti ödenmiş olunabilmektedir. Optimizasyon yapılması, zamanında aksiyon almaya firsat tanımasıyla birlikte operasyon ve maliyet iyileştirmesi, aynı zamanda iş güvenliği ve kalite standartlarının takibi ve iyileştirmesi gibi katkılar sağlamaktadır.

\section{Rakip Firmalarla Kıyaslaması}

Hızlı tüketim ürünleri sektöründe diğer büyük firmalarda aynı şekilde SAP sistemi kullanmaktadır. Ancak 'ABC' şirketinin kullandığı kurum içi bilgi paylaşım sistemi (FOL) gibi yazılımlar ve yenilikçi yaklaşım sayesinde biraz daha önde sayılabilmektedir. Otomasyonda çok iyi seviyeyi yakalamış bulunmaktadır. Bu lokasyonudaki fabrika \%97 oranında otomasyonla çalışmaktadır. Otomasyon sistemi kullanılan kısımlar, üretim, yükleme, hammadde teslim alma bunların hepsini kapsamaktadır. Şirket bu konuda rakiplerinden öne çıkmaktadır. Çünkü daha hızlı yükleyebilmekteler, daha hızlı mal çekişi yapabilmekteler, daha hızlı sistemleri kontrol ederek maliyet çalışabilmekteler ve daha hızlı aksiyon alabilmekteler. Şu an piyasadaki en önemli şey hız olarak görülmektedir. Bir ürünü artık herkes yapabilmekte iken bunu en erken piyasaya çıkaran kazanmaktadır. Kısacası en erken karar alanın kazandığı görülmektedir. Şirketi kullandığı yazılım programları, dijitalleşme ve otomasyon programları ile ilgili yaptığı yatırımlar öne çıkarmaktadır.

\section{Mevcut Sistem Önerileri}

Firmada kullanılan mevcut sistem için sürücü dostu aplikasyonlar geliştirilmesi, uygulamalarda sürücünün iş bulma şansının arttırılması gibi öneriler sunabilmektedir. SAP'nin depo yönetim (WM) modülü çok esnek bir yapıya sahip olmadığı için zaman zaman şirket çalışanları onu değiştirmeye yönelik öneriler sunmaktadırlar. Yani dışarıdan SAP ile bütünleşmiş olarak şirket kendi esnek programını kullanmayı tavsiye etmektedir. Depo yönetim(WM) modülünde paletlerin hangi rafta olduğu görülmektedir. Ancak aslında bu sadece depo çalışanlarını ilgilendirmektedir. $\mathrm{Bu}$ bilgiler herkese açık bir sistemde kayıtlı olduğu için ilgili olmayan departmanlar gereksiz bilgileri görmektedirler. Dışarıdan bir satış departmanı veya planlama departmanı stokta ne var diye baktığı takdirde ürünün hangi rafta olduğu onun için önemli olmamaktadır. Yalnızca son kullanma tarihi önemli olabilmektedir. Bu departmanlar geliş tarihi bilgisini yeterli bulmaktadırlar. Dolayısıyla depo yönetimi depo ekibi dışında hiçbir yeri etkilememektedir. Fakat örneğin kalite departmanı bu bilgileri bloke ettiğinde, bir başka tarafta başka sıkıntılara yol açmaktadır. Kısacası hantal bir program gibi görülebilmektedir.

Şirket personelinin önerisi, başka departmanlar bu durumdan etkilendiği için şirketin kendi bünyesinde buna ayrı bir yazılım kullandığı takdirde hiçbir departmanın bu durumdan etkilenmemesi öngörülmekte ve bunun sonucunda ilgili departman sadece bu yazılımın çıkardığı stokları görebilmesi beklenmektedir. Bu sayede de departmanların kendi içerisinde daha esnek olması sağlanabilmektedir. SAP programında değişim yapılması oldukça zor olmaktadır. Buna örnek olarak belirli numarada bir ürünün askıya düştüğü tespit edilmekte ve ilgili personel 
problemi sisteme girdiğinde tüm sistem aynı anda entegre olduğu için tekrar değişiklik talebinde bulunulduğunda hantallık meydana getirmektedir.

\section{Lojistik Faaliyetler SWOT Analizi}

Tablo 5: Swot Analizi

\begin{tabular}{l}
\hline GÜÇLÜ YÖNLER \\
\hline ABC firması köklü ve büyük pek \\
çok şirket ile çalışmaktadır. Bu \\
durum şirkete güç ve prestij \\
katmaktadır.
\end{tabular}

\section{FIRSATLAR}

Şirket üçüncü parti lojistik (3PL) firması ile çalıştı̆̆ için işleri başkası şirket adına yapmaktadır. Fakat onlar müşteri memnuniyetine şirket kadar riayet etmeyebilmektedirler. Özellikle lojistik sektöründe çok profesyonel firmalar bulunmamaktadır. Şirket her ne kadar dikkat etse de görevli şoförün bakış açısı tamamen firmayı temsil etmektedir. Şoförün davranışları bir nevi şirket imajını yansıtmaktadır. Şirket için üçüncü parti lojistik (3PL) firması ile çalışmanın imaj ve müşteri memnuniyeti açısından riskleri bulunmaktadır.

\section{ZAYIF YÖNLER}

Şirketin kararlarını uygulamada zorluk yaşamaktadırlar. Şirkette iş güvenliği noktasında ciddi politikalar uygulanmaktadır. Bu duruma örnek olarak şirketin iş kazası olarak Antalya da herhangi bir şoförün, şirketin kendi ürününü distribütöre taşırken orada bir kaza yaptığında şirketin kendi kazası gibi kayıt alması gösterilmektedir. Şirket ürününü taşıyan bir şoförün nasıl bir kaza yaptığını çözülmesi gereken bir problem olarak görmektedir. $\mathrm{Bu}$ durum ise şirkete külfet olmaktadır. Kaza sebebi sorgulanmakta ve kaza yerine gidilerek oradaki tedarikçisinden bilgi almaktadır. Tedarikçinin şoföre hangi maldan ne kadar verdiği, saat kaçta verdiği, şoförün kaç saat uykusuz olduğu gibi detaylar öğrenilmektedir. Aracında olması gerekenlerin olup olmadığını, kontrol edip etmediği bilgilerinin hepsi sorgulanmaktadır.

Şirketin sosyal açıdan çok ciddi hedefleri bulunmaktadır. Ancak şirketin bunları, kendi aracıyla çalışmadığı için uygulaması oldukça zor olmaktadır. Örneğin şirketin personel servis araçları bulunmaktadır. Arabaya bindiklerinde emniyet kemerini takmadan araç hareket etmemektedir. Yolcuların yerlerine oturmaları ve emniyet kemerlerini takmaları ile ilgili ikaz anonsları yapılmaktadır. Bu araçlarda GPS bulunmaktadır. Araçla ilgili her detay şirket tarafindan kontrol edilebilmektedir. Şoförlerin hızını, güvensiz risk yapıp yapmadığı ve ani fren yapıp yapmadığı bilgileri takip edilebilmektedir. Bu ayrı bir güvenlik komitesi tarafindan yönetilmektedir. Bazıları bu kurallara uymakta, bazıları uymamaktadır. Önceleri ceza sistemi denenmiş ancak başarılı olunamamıştır. Ödüllendirme sistemine geçmişlerdir. Sistem; Hepsinden 93 puan aldığınız takdirde şirket ürünlerinden bir hediye paketi verilmektedir. Bu sisteme geçildikten sonra düzeldiği görülmektedir. Şirket fabrika içinde aynı kişilerle çalıştığg için devamlı olarak bu kişileri kontrol edebilmektedir. Ama üçüncü parti lojistik (3PL) firmaları ile çalıştıklarında kontrol edilmesi çok zor olduğu halde bir taraftan da ulaşmayı planladığı hedefleri bulunmaktadır. Bu şirketin zayıf yönü olmaktadır.

Şirketin öz mal aracı olmadığı için istediği zaman değiştirebilmektedir. Yenileme konusunda hızlı esneyebilmektedir. Daha çevik hareket edebilme şansları olmaktadır. Şirketin kendi araçları için bu kararı alması oldukça zor olmaktadır. Ancak bir firmayla çalıştığında en fazla 1-2 yıl sözleşme olduğundan dolayı, sözleşme bitiminde başka bir karar alabilmektedirler. Örneğin Amazon firmasının zeplinle taşıma denemeleri bulunmaktadır. Bunlar belki yalnızca deneme olarak kalacak belki 10 sene sonra ancak yapılabilecek, belki de yapılmayacaktır. Ancak bu denemeler başka fikirlerin kapısını açmaktadır. Bu tarz çalışmalar müşteriye doğrudan teslimatı sağlamak için denenmektedir. Ve bu yeniliklere de herkes ayak uydurmak zorunda kalmaktadır, geç kalan yarıştan çekilmektedir. Artık teknoloji çok hızlı ilerlemektedir. Eskiden telefonlar belki de 5-10 senede bir yenilenebiliyorken şimdi ise her yıl yenilenmektedir. Eskiden arabalar 5-6 sene aynı model kasa çıkarırlarken şimdi 2 senede bir kasada ufak değişiklikler yapmaktadırlar. Çünkü değişimin hızlandığı herkes tarafindan kabul edilmektedir. İhtiyaç artık hılı gelmekte ve bunlara şirketlerin ne kadar erken ayak uydurabildiği kritik nokta olmaktadır. 


\section{Dijital Dönüşüm Kapsamında}

Dijital sistemler bulunmakta ancak daha fazla geliştirilmesi gerekmektedir. Örneğin sistemde buradan planlama verileri girildiği takdirde doğrudan üretime gitmektedir. Ancak bazı sistemlerde şirket planlamayı da girmeden üretim bittiğinde o ürünün kapanmasını istemektedir ve sırada yeni ürün varsa hemen sisteme otomatik açması gerekmekte ve o kısımda oradan direk görülmesi gerekmektedir.

Şirketin çevrimiçi otomatik takip sistemleri bulunmaktadır. Bunlar depo tiplerine göre belirlenmektedir. Merkezde de bunların hepsini görebilmektedir. Diğer türlü olduğunda personel ürünü hatalı sayarak yanlış bilgiyi iletmekte ve bilgi verdiği departman da bu sebeple hatalı bilgi girişi yapmaktadır. Ayrıca sayımı unutulan ürünler de bulunmaktadır bu durum da hata olasılığını artırmaktadir.

Firmada nesnelerin interneti (IOT) teknolojisine örnek olarak otomatik yönlendirmeli araçlar (AGV) ve rampaya yanaşan otomatik kamyonlar örnek verilebilmektedir. Otomatik yönlendirmeli araçlar (AGV) için üretim içerisinde ürünlerin kapak paletlerinin koyulduğu bir istasyon bulunmaktadır. Otomatik yönlendirmeli araçlar (AGV) öncelikle bu istasyona malı koymaktalar, daha sonra bu mal istasyonda bittiğinde sensor boşa geçmektedir. Boş kaldığında da otomatik yönlendirmeli araçlar (AGV) tarafından otomatik sisteme girilmektedir. Halen aynı üretim devam ediyorsa da otomatik yönlendirmeli araçlar/AGV) sisteme boşta kaldığının ve palet üretilmesi gerektiğinin uyarısını vermektedir. Otomatik yönlendirmeli araçlara (AGV) sistemden emir gelmektedir. Aynı zamanda da bu emir forklift operatörüne de gelmektedir. Forklift operatörü kontrolü sağlayarak, ihtiyaca göre deponun içerisindeki istasyona götürüp paleti yerleștirmektedir. Otomatik yönlendirmeli araçlar (AGV) palet geldiği uyarısını doğrudan sistemden alarak, kendi yerine otomatik gitmekte ve paleti almaktadır. Beslemesi gereken kısmı besledikten sonra sırasını beklemekte ve ardından şarjı bittiğinde de kendi kendine şarja paneline gitmektedir. Tüm bunların hepsi otomatik gerçekleşmektedir.

\section{Sonuç}

Araştırma da lojistik faaliyetlerde kullanılan bilişim teknolojilerinin şirket üzerindeki etkileri incelenmiştir. Dijital dönüşüm kavramı kapsamında, iş süreçlerinde gidilecek teknolojik bir değişim ile lojistiğin tüm unsurlarında etkin ve verimli olarak sistemleri ve süreçleri geliştirmenin mümkün olabileceği gözlemlenmiştir. Ancak bu olumlu etkinin oluşabilmesinin şirket yapısına bağlı olduğu da tespit edilmiştir. Örneklem alınan firmanın küresel boyutlarda olan ve pazar payı güçlü olan bir firma olduğu da göz önüne alınmalıdır. Dolayısıyla bu üretim işletmesinde görüldüğü üzere tüm lojistik faaliyetler şirket içerisindeki diğer organizasyon alanlarına doğrudan veya dolaylı olarak etki sağlamaktadır. $\mathrm{Bu}$ etkiler şirketin iş süreçlerini hızlandırmakta, verimliliğini artırmakta, çevik karar alma mekanizmasının gelişmesini sağlamakta, üretim performanslarını maksimuma çıkarırken maliyet denetimini kolaylaştırdığı için alınabilecek optimum sonucun alınmasını sağlamakta ve şirket içi ve dişı her bilginin tek bir noktada birleşmesini sağlayarak anlık bilgi akışının önünü açmaktadır.

Çalışma sonucunda bir üretim işletmesinde lojistik faaliyetlerin etkisinin oldukça yüksek olduğu görülmektedir ve bununla birlikte bilişim teknolojileri ile performans düzeyi artırılan faaliyet oldukça olumlu sonuçlar doğurmaktadır. Bu etkileri artıracak olan bilişim teknolojilerinin firma üzerindeki etkisi incelenmiş ve pek çok alanda olumlu sonuçlar doğurduğu gözlemlenmiştir. Ayrıca lojistik faaliyetlerle bağlantılı olan şirket içi organizasyon yapısı açıklamalarda detaylı bir şekilde sunulmuştur. Şirket yetkilisinin yarı biçimsel mülakat tekniği ile paylaymış olduğu önerilere de metinde yer verilerek, gelecek araştırmalara 1 şık tutması sağlanmıştır. Çalışma içerisinde yer verilen görsellerle ve tablolarla metin desteklenmiştir. Şirket içerisinde kullanılan yazılım sisteminin ortaya koyduğu etkilerden dönüşümün yalnızca teknolojik tabanlı olmadığı bilgi temeline dayandığı da görülmektedir. Sonuç olarak çalışmanın başında öngörülen, işletmede 
lojistik yönetiminde bilişim teknolojilerinin kullanımı ile işletme faaliyetleri arasında ve müşteri memnuniyeti arasında bir ilişki vardır hipotezi araştırma sonucun verdiği bilgilerle desteklenmiştir.

\section{Kaynakça}

Aydıner A.S. ve Tatoğlu E. (2019). Türkiye'deki işletmelerde bilişim sistemleri uygulamaları üzerine bir saha araştırması. Bilişsim teknolojileri dergisi, Cilt:12(1),59-73.

Chaudhari B. ve Patel B. (2017). Future of big data. International research journal of engineering and technology (IRJET), 4(1), 597. Erişim tarihi: 3 Kasım 2019, IRJET.

Çağlar, M.B. (2014). Lojistik İşletmelerinde Bilişim Teknolojilerinin Kullanımı, Müşteri Memnuniyeti ve İşletme Performansı İlişkisi: Bir Araştırma. Selçuk Üniversitesi Sosyal Bilimler Dergisi, 32, 41-55.

Drucker, P. F. (1988). Thecoming of theneworganization, Harwardbusinessreview, s.3-11.

Greengard S. (2017). Nesnelerin İnterneti, Optimist Yayım Dağıtım San. ve Tic. Ltd. Şti., (Müge Çavdar, Çev.). The MIT Press. (Orjinal eserin yayın tarihi 2015).

Power, N. C. (2000). Global trends in education. International educationjournal, Vol. 3. p. 1-6.

Temel, H. Y., ve Yaprakl1, H. (2015). Küreselleşen dünyada işsizlik.

Yankın, F.B. (2019). Dijital dönüşüm sürecinde çalışma yaşamı. Edirne: Trakya üniversitesi iktisadi ve idari bilimler fakültesi e-dergi, 7(2), 1-38.

Yin, R. K. (1994). Case studyresearch, designandmethods. ThousandOaks, Kaliforniya, ABD: Sage Yayınları. 